\title{
5 \\ The London Naval Conference and the Manchurian Incident
}

\section{China and the Soviet Union}

\section{The Hamaguchi Cabinet and Shidehara's Personnel}

July 1929 marked the beginning of the Minseitō party cabinet, led by Hamaguchi Osachi. When the imperial order to form a cabinet was issued, Hamaguchi's reply to the throne included the names of Ugaki Kazushige, Inoue Junnosuke and Shidehara Kijūrō as cabinet minister nominees. Ugaki, Inoue and Shidehara would take over the positions of war minister, finance minister and foreign minister, respectively. Shidehara had anticipated that he would be able to return to the position of foreign minister at this time. Shidehara and Hamaguchi were old friends from school days; their school, what would become the Third Higher Middle School, had been relocated from Osaka to Kyoto while they were in attendance. Shidehara was also 56 years old and now reaching the end of middle age. The Hamaguchi cabinet announced that it would pursue a platform of 10 major policies, including the reform of Chinese policy, a reduction in the size of the military, a curtailment of public finance and a lifting of the gold embargo. 
Now that he was once again serving as foreign minister, what kind of diplomatic efforts did Shidehara initially undertake? Let us answer that question by first looking at the matter of ministry personnel. The shift that is generally referred to as 'Shidehara personnel' would begin at the end of the following year, 1930. At that time, Shidehara installed Nagai Matsuzō and Matsuda Michikazu as vice-minister and Treaties and Conventions Bureau director-general, respectively. ${ }^{1}$ That is to say that, for a period of over a year following his return to office, Shidehara avoided making any significant personnel changes. Presumably, Shidehara could have conducted an early reshuffle of individuals such as the Tanaka-cabinetaligned vice-minister Yoshida Shigeru. However, Shidehara decided that he 'could not consent to administrative-level staffing changes directly following the assumption of office'. ${ }^{2}$ This meant that Vice-Minister Yoshida and the various bureau directors-general retained their positions for a time.

Debuchi Katsuji, who had supported Shidehara during his first term as foreign minister, had already become ambassador to the US by this point. Meanwhile, his other trusted subordinate, Saburi Sadao, was now a counsellor at the British embassy. There, Saburi undertook actions such as visiting the Chamber of Commerce and Industry in Manchester to discuss trade with China. ${ }^{3}$

Before long, Saburi was internally selected to serve as ambassador to the Soviet Union. However, Shidehara instead sent him to China as Japan's minister. Unfortunately, this decision led to tragedy. Only a short time after becoming the minister to China, Saburi returned to Japan in November 1929 to discuss with Shidehara the future direction of Chinese policy. Just after these discussions, on 29 November, Saburi was discovered dead in his hotel in Hakone in suspicious circumstances. He had been minister to China for only one month. Upon receiving this shocking news, Shidehara decided that Saburi's death must have been a murder. This was because 'he held a pistol in his right hand. As it happens, the pistol bullet entered his head from the left temple and exited on the right'. Nevertheless, a theory spread widely that he committed suicide due to anguish over his wife's death and Sino-Japanese relations. Shidehara strongly rejected this theory, stating: 'Our discussions had concluded positively, and he had departed in good spirits, intending to enjoy himself [Hakone is a town popular for its recuperative hot springs]. This is an absolute fact'. ${ }^{4}$ 
Was Saburi murdered, as Shidehara asserted? Certainly, the suggestion that the bullet entered through his left temple lends some weight to this interpretation. However, this was an early rumour. An autopsy later found that the bullet entered not from the left temple but from the right. The police also determined that it was suicide. Shidehara would have been aware of these facts. Perhaps Shidehara simply did not want to admit that Saburi could have killed himself. ${ }^{5}$

Within the diplomatic corps, there were others who, unlike Shidehara, believed the suicide thesis. Shigemitsu Mamoru was one such individual. At the time, Shigemitsu was consul general in Shanghai. Shigemitsu and Saburi had a friendly relationship from the time of the Paris Peace Conference. In the past, on the occasion of the Beijing Special Conference on Tariffs, the two had worked on the announcement that Japan was prepared to recognise China's tariff autonomy. Together they had sought to lead policy on China from the front lines. The Nationalist government therefore welcomed the news that Shidehara was appointing Saburi as Japan's minister to China. According to Shigemitsu, when he temporarily returned to Japan, Saburi had attempted to convince Shidehara that 'for Japan the true problem of essential importance is the China problem'. Yet the leadership of the Ministry of Foreign Affairs was buried in work dealing with other matters, such as reductions in the size of the military. Saburi apparently complained to Shigemitsu that they simply won't consider the matter seriously'. ${ }^{6}$ Given that Saburi's wife had already passed away, Shigemitsu saw his death as a suicide arising from loneliness. Horinouchi Kensuke, counsellor to the Japanese legation in China, had a similar interpretation of Saburi's death. ${ }^{7}$

In any case, Saburi's death must have been a serious blow to Shidehara. At the same time, however, he now had to decide who would replace Saburi as minister to China. In December 1929, he selected Obata Yūkichi for the role. Obata had previously headed the Political Affairs Bureau when Shidehara was vice-minister. The Chinese side, however, indicated that it was not inclined to reach an agrément on Obata. In diplomatic language, an agrément is the acknowledgement a nation gives before the appointment of a minister or similar dignitary who would be dispatched there. The reason the Chinese were concerned about Obata was that he had worked as first secretary at the Japanese legation in China at the time of the Twenty-One Demands. Further, China's foreign minister, Wang Zhengting, had issued a surprising condition: China would only give its agrément if the legation was upgraded to an embassy. There was no way 
that Shidehara would accept what he considered to be a preposterous demand. In his opinion, the promotion to the embassy should have had nothing to do with the agrément. In the first place, Obata had worked at the legation for some time following the Twenty-One Demands from 1918 to 1923 . In the end, the Nationalist government refused to issue an agrément for Obata. ${ }^{8}$

\section{China and the Soviet Union}

During this period, some significant shifts occurred within China. When Shidehara returned to the position of foreign minister, a dispute broke out between China and the Soviet Union regarding the Chinese Eastern Railway. Located in north-eastern China, this railway was jointly managed by the Soviet Union and China. In July 1929, however, China attempted to regain full control over the railway. In response, the Soviet Union cut off diplomatic relations with the Chinese government. Events then escalated, with the Soviets launching a military incursion into Chinese territory in November. The north-eastern border towns of Manzhouli and Hailar were overrun. This Sino-Soviet conflict of 1929 ended in total victory for the Soviet side, and, in December, the two nations signed a protocol returning the Chinese Eastern Railway to its former state.

Shidehara's policy on responding to the Sino-Soviet conflict had two major features. First, he had Japan directly mediate negotiations between China and the Soviet Union. Believing that the Chinese policy of retaking the Chinese Eastern Railway was 'a plan to retake Russia's interests under the pretense of anti-Bolshevization', Shidehara closely questioned China's minister to Japan, Wang Rongbao. In this sense, Shidehara's response can be considered somewhat favourable towards the Soviet Union, even if only slightly. Second, Shidehara avoided adding Japan's voice to the multilaterally negotiated mediation by US Secretary of State Henry L. Stimson. Shidehara, who was assisting the unofficial negotiations between China and the Soviet Union, believed that Stimson's plan 'would only further inflame the feelings of the nations involved and could not be expected to yield positive results'. ${ }^{9}$ Hence, although closely involved in the talks between the two nations, Shidehara kept the details of those talks secret. Later, he would boast that this kind of secret diplomacy was effective. 
Around this time, there was another issue with implications for Sino-Japanese relations. A document of dubious origin known as the 'Tanaka Memorial' was circulating within China. The Tanaka Memorial purported to be a report by Prime Minister Tanaka Giichi to the Shōwa emperor. The contents were a plan for the invasion of China based upon the discussions held during the aforementioned Tōhō Kaigi (Eastern Summit). However, the details of the document differed significantly from the actual discussions held at the summit, and it is highly likely that it was forged in north-eastern China in the first half of 1929. On 16 September 1929, the acting minister to China, Horinouchi Kensuke, sent a telegram to Shidehara. According to this telegram, Cheng Liting, chief secretary for the Shanghai YMCA, planned to read the Tanaka Memorial aloud at the Kyoto conference of the Taiheiyō Mondai Chōsakai (Investigative Committee for the Pacific Problem). This civil international investigative committee was established for the purpose of mutual understanding; it was also known in English as the Institute of Pacific Relations (IPR). ${ }^{10}$ IPR members included experts from Japan, the US and China, and the IPR had previously convened in Honolulu in 1925. Along with the general secretary of the YMCA in China, Yu Rizhang, Cheng Liting was a central figure in the IPR. ${ }^{11}$

At the time of the Honolulu conference, Shidehara displayed a cooperative attitude towards the IPR. He once stated to a US associate of the group that he thought 'this kind of unofficial conference can help to foster mutual understanding between the citizens of the various [Pacific] nations'. ${ }^{12}$ However, at the Kyoto conference of the IPR, held in the autumn of 1929, the Asian Bureau and Intelligence Department of Japanese Ministry of Foreign Affairs stepped in to prevent the reading out of the Tanaka Memorial. Regardless, the Tanaka Memorial became widely distributed within China in pamphlet form, and even Chinese newspapers and magazines published its contents. This development led Shidehara to issue warnings in February 1930 to the various consuls general stationed in China. Guiding Japan's Chinese policy in the field at this time was Shigemitsu, acting minister to China. Shigemitsu's response to the problem represented by the Tanaka Memorial was to ask the Chinese government to crack down on its circulation. On this occasion, Shigemitsu also took the opportunity to thoroughly point out the fundamental mistakes visible in the document, and the Foreign Ministry of the Nationalist government showed signs that they would indeed take steps to deal with the matter. This appears to indicate that the Chinese side knew that the document was a forgery. 
It is also worth noting that, during this period, Shidehara became the chairman of an arbitration committee established according to the guidelines of a treaty signed between the US and Germany. This arbitration committee would be tasked with helping the two nations reach an amicable settlement in the event of a conflict. While the US and Germany each selected two members to sit on the committee, the chairman was to be selected from a third nation that was trusted by both. Their agreed-upon choice was Shidehara. However, given the lack of a conflict, the role did not involve much work. ${ }^{13}$

\section{The London Naval Conference on Disarmament}

\section{Party Politics and Japan-US Relations}

Shidehara's greatest achievement during his second term as foreign minister was the London Naval Conference on Disarmament. ${ }^{14}$ The aim of this international conference, held in London in the first half of 1930, was to limit the number of auxiliary warships among the participating nations. Before looking at the strategy Shidehara deployed, let us first review the circumstances leading up to the conference. Naturally, the precursor to the London Naval Conference was the Washington Naval Conference. As mentioned earlier, the Washington Naval Conference was held from November 1921 to February 1922. The naval disarmament agreed upon at this conference only limited the number of capital ships that participants could have. This led to an auxiliary ship construction race between the major powers in the years following the conference. Later, in the summer of 1927, a naval disarmament conference was held in Geneva to place limits on auxiliary ships as well. However, due to disagreements, including a confrontation between the UK and the US, the Geneva Conference was a failure. This was the background leading up to the 1930 London Naval Conference.

The London Naval Conference was attended by Japan, the UK, the US, France and Italy. Leading Japan's delegation, the Hamaguchi cabinet sent former prime minister Wakatsuki Reijirō and Navy Minister Takarabe Takeshi. The policy of the Hamaguchi cabinet included the goal of securing an auxiliary warship ratio of 70 per cent relative to the US in terms of total tonnage. This goal made compromise between Japan and 
the US quite difficult. Nevertheless, the representatives of the two nations reached an understanding whereby, among other things, the total tonnage of Japanese vessels would be permitted to reach 69.75 per cent relative to the US. Although the Japanese navy were unhappy with a number that was lower than their initial goal, the Hamaguchi cabinet accepted this compromise. The resulting treaty, the London Naval Treaty, was signed in April 1930. It can be considered a success for Japanese diplomacy.

The figures who were ultimately responsible for leading the conference to its successful conclusion were Foreign Minister Shidehara and Prime Minister Hamaguchi. The ratification of the London Naval Treaty as a result of their political guidance marked a high point for cooperative diplomacy in the history of modern Japanese party politics. Nevertheless, prewar party politics in Japan was fated for an early end. Strictly speaking, the period of party politics began with the formation of the Kato cabinet in June 1924 and ended with the May 15 Incident of 1932. As was revealed by the Manchurian Incident, an indirect cause of the collapse of party politics in Japan was that the political parties did not clearly define a system for guiding the nation's diplomatic efforts.

In this sense, the London Naval Treaty was a turning point. That is to say, while the Hamaguchi cabinet was certainly proactive in politically guiding the outcome, it led to another problem: the problem of supreme command interference. The concept of supreme command refers to the highest authority over the military, and, according to the Meiji Constitution, this highest authority was the emperor. Following the conclusion of the London Naval Treaty, the Seiyūkai opposition party was, therefore, able to accuse the Hamaguchi cabinet of supreme command interference-a problem that could potentially undermine the foundation of party politics.

The London Naval Conference was also quite important for relations between Japan and the US. As it happened, a group more familiar with, and sympathetic towards, Japan was beginning to take shape in the US State Department. ${ }^{15}$ It should be noted that, because it was conflict between the UK and the US that had led the earlier Geneva Conference to run aground, both nations had had detailed consultations before the main event. The UK had also succeeded in decoding important telegrams from the Japanese Ministry of Foreign Affairs. Meanwhile, the Japanese navy continued in its tradition of viewing the US as a hypothetical 
enemy. It was therefore anticipated that the debate surrounding naval disarmament would be most contentious between Japan and the US. And, indeed, the Japanese-American relationship dominated the conference. ${ }^{16}$

Keeping these facts in mind, we can now consider the details of the London Naval Conference, which has been viewed as a high point in prewar Japanese democracy. In this overview I will consider not only Shidehara's perspective but also that of the US ambassador to Japan, William R. Castle, Jr. This approach will be of assistance for considering the maturity of party politics in Japan. There are three major points to consider.

This first is the internal processes in the Japanese Ministry of Foreign Affairs and, in particular, the relationship between Foreign Minister Shidehara and Vice-Minister Yoshida. From the time Yoshida was consul general in Mukden, his and Shidehara's policies on China began to diverge. Yoshida became vice-minister through his close association with the Tanaka cabinet, yet he was left in the role by Shidehara with the beginning of the Hamaguchi cabinet. This meant that the relationship between the two individuals was somewhat delicate. However, during the London Naval Conference, Yoshida would take Shidehara's opinions on board with respect to US policy, while making every effort to coordinate with Castle, the imperial court and the military.

Second, we need to consider Castle's actions and his perspective on Japan. As the US ambassador to Japan, Castle was a representative figure of the pro-Japanese faction in the State Department. Along with diplomatic telegrams, Castle also left behind documentation such as a detailed diary, correspondence and speech drafts. ${ }^{17}$ If we examine these sources, we find, at times, unexpected evaluations of Japan's Ministry of Foreign Affairs, its political parties, the imperial household and other subjects. I suggest that such resources can not only serve as a guide to Castle's relationship with Shidehara but also may be helpful for considering contemporary Japanese party politics.

Third, we need to consider the possibilities and limits of any new order that could be reached through Japanese-American cooperation. The London Naval Conference was not an isolated phenomenon. It also included attempts to expand Japan-US cooperation to matters such as the 'China problem', as well as the immigration problem. This means that there was a latent possibility that international politics in this period could 
head towards the construction of a more stable global order, with the London Naval Conference serving as a foothold. While Shidehara is my main focus regarding this topic, I will also examine the actions of Castle, Secretary of State Stimson, State Department Division of Far Eastern Affairs Chief Hornbeck, ambassador to the US Debuchi and others. In this way, I aim to shed further light on barriers to the construction of a new international order, as well as the nature of the relationship between naval disarmament on the one hand and both the China and immigration problems on the other.

\section{Shidehara and Castle}

Before Castle was sent to Japan as the US ambassador at the time of the London Naval Conference, he worked for nearly three years as assistant secretary of state. Shidehara welcomed Castle's appointment as US ambassador, as Castle learned from Ambassador Debuchi. Castle had also thought for some time that Shidehara was trustworthy. ${ }^{18}$ The personal relationship between Castle and President Herbert Hoover was also generally positive. ${ }^{19}$ Conversely, there was some discord between Castle and Secretary of State Stimson at the time of the Sino-Soviet conflict in the second half of 1929. ${ }^{20}$ While attending the London Naval Conference, Stimson requested that Undersecretary of State Joseph P. Cotton serve as acting secretary of state.

Meanwhile, in the lead-up to the London Naval Conference, the Hamaguchi cabinet made a number of planned attendees plenipotentiaries. These attendees included former prime minister Wakatsuki Reijirō as chief delegate; he would be accompanied by Navy Minister Admiral Takarabe Takeshi, ambassador to the UK Matsudaira Tsuneo and ambassador to Belgium Nagai Matsuzō. Further, Admiral Abo Kiyokazu and Admiral Sakonji Seizō were appointed as adviser and chief attendant, respectively. On 26 November 1929, the cabinet further decided upon three fundamental principles for the conference: auxiliary warship tonnage at 70 per cent of the US total, large cruisers at 70 per cent of the US total and the preservation of the current number of submersibles. ${ }^{21}$

Following the precedent of the Washington Naval Conference, Hamaguchi assigned multiple individuals to help the navy minister with his administrative responsibilities. These were the vice-minister of the Navy Ministry; Vice Admiral Yamanashi Katsunoshin; the chief of Bureau of Naval Affairs, Major General Hori Teikichi; and, as their assistant, senior 
aide Colonel Koga Mineichi. I also note that, at that time, the chief of the Naval General Staff was Admiral Katō Hiroharu, the vice chief was Vice Admiral Suetsugu Nobumasa and the chief of the First Bureau was Rear Admiral Katō Takayoshi. On the US side, the plenipotentiary delegation was headed by Secretary of State Stimson. The delegation also included the US ambassador to the UK, Charles G. Dawes; Secretary of the Navy Charles Francis Adams; a Democratic senator, Joseph T. Robinson; a Republican senator, David A. Reed; the ambassador to Belgium, Hugh S. Gibson; and the ambassador to Mexico, Dwight W. Morrow. The British representatives, meanwhile, were led by Prime Minister J. Ramsay MacDonald, who also chaired the conference. They included Foreign Secretary Arthur Henderson and Secretary for the Navy Albert Victor Alexander. Meanwhile, the French and Italian chief delegates were Prime Minister André P. G. A. Tardieu and Foreign Minister Dino Grandi di Mordano, respectively. On 9 January 1930, Japan's three representatives, Wakatsuki, Takarabe and Matsudaira, visited MacDonald at the prime minister's residence for informal talks. ${ }^{22}$

Castle, meanwhile, arrived at Yokohama via Honolulu on 20 January. Shidehara immediately received him as a visitor. Castle's task was to take over from acting US ambassador Neville. ${ }^{23}$ On 24 January, Shidehara and his wife dined with Castle. They were joined by former ambassador to the US Hanihara Masanao, Vice-Minister for Foreign Affairs Yoshida Shigeru and Asian Bureau Director-General Arita Hachirō. The Shideharas were apparently in good spirits that evening. On the same day, Castle also met Nelson T. Johnson, the US consul to China, who was then visiting Japan. In his diary, Castle wrote: 'Nelson and I agree very largely on Far Eastern Questions, although I am not sure that he would agree that Japanese friendship is more important than Chinese'. ${ }^{24}$

It might also be asked how Shidehara appeared to Castle. In correspondence with President Hoover, dated 27 January, Castle relayed his first impressions of the Hamaguchi cabinet:

Shidehara is really a statesman, farseeing and broad minded, and Hamaguchi, the Prime Minister, is a man of high integrity. It would be difficult to find another man as Finance Minister as able, courageous and experienced as Inoue..$^{25}$

Castle added: 'We cannot ignore the fact that Japan as truly has special interests in Manchuria as we have in Cuba'. ${ }^{26}$ 


\section{'Certain Thoughtful Japanese'-Foreign Minister Shidehara}

Thus, Shidehara had the opportunity to strengthen his relationship with Castle. In a telegram sent on 14 February to Secretary of State Cotton, Castle reported that 'certain thoughtful Japanese' regretted that a 70 per cent tonnage ratio had been adopted as a critical target. ${ }^{27}$ By 'certain thoughtful Japanese', Castle presumably meant the leaders of the Ministry of Foreign Affairs, beginning with Shidehara. In fact, Castle had met with Shidehara on that day and had informed him that even if Japan were limited to a 60 per cent tonnage ratio, the US navy would not regard an attack on Japan as viable. According to Castle, the US public worried that a build-up of the Japanese navy might lead to a future invasion of the Philippines. Shidehara replied that even if Japan initially succeeded in occupying the Philippines, 'it would be the beginning only of a war which in the end must be the ruin of Japan'. ${ }^{28}$

What was disturbing for Castle was the gap between Shidehara, who had extensive knowledge of the realities of international affairs, and public opinion in both Japan and the US, which was dominated by fear of possible conflict. For example, Hirata Shinsaku published an essay in the journal Nihon oyobi Nihonjin (Japan and the Japanese) titled 'Beikoku Taishi Sai-Kaiken-ki' (Records of another meeting with the US ambassador). The essay included a depiction of military commentator Hirata directly pressing Castle and First Secretary Dooman. According to this depiction, when speaking with Shidehara, Castle once threatened that the US Air Force would be capable of bombing Tokyo. ${ }^{29}$ However, Castle did not actually threaten the bombing of Tokyo, and Shidehara and Castle got on quite well.

Shidehara and Castle were troubled by these trends in public opinion. Nevertheless, on 20 February, they received some positive news: the Minseitō had achieved an outright victory in the general election. This meant that the Hamaguchi cabinet was now in a position to carry out some bolder policies. Further, there was also a change in government in France with the formation of a cabinet led by G. Camille Chautemps. Until then, France had been holding back the proceedings at the London Naval Conference, and other participants hoped that a new French government would lead to greater progress. At this time, Castle sounded 
out Shidehara on the possibility of excluding France and Italy and reaching a tripartite agreement with the US and the UK. Shidehara gave a favourable response. ${ }^{30}$

On 26 February, the London Naval Conference split into the 'European Group' of the UK, France and Italy, and the 'High Seas Group' of the UK, the US and Japan. ${ }^{31}$ To ensure that the preliminary negotiations of the latter would be smooth, Japan and the US in turn began with their own unofficial talks, held between Matsudaira and Reed. Likewise, JapaneseBritish negotiations were held between Saitō Hiroshi, director-general of the Intelligence Department of the Japanese Ministry of Foreign Affairs, and Robert Leslie Craigie, chief of the American Department of the British Foreign Office. Of these, it was the talks between Matsudaira and Reed that began to show signs of reaching a breakthrough. Shidehara himself was inclined to accept the US proposal regarding cruisers. However, he was concerned about opposition from the Japanese navy. In the end, Castle convinced him that it was now Japan's turn to make a compromise. ${ }^{32}$

On 13 March, Japan and the US agreed on a compromise proposal: Japan's auxiliary vessel tonnage would be set to 69.75 per cent of that of the US, and submarine tonnage between Japan, the UK and the US would be set at the same level. The following day, seeking approval of the proposal from the government at home, the Japanese delegation to London sent a telegram stating that the U.S. side has for all practical purposes already agreed to a general 70 per cent principle'..$^{33}$ Castle had also emphasised to Shidehara that this proposal would be the US's final concession. On 15 March, Shidehara visited Hamaguchi with this telegram in hand. Upon receiving it, Hamaguchi summoned Navy ViceMinister Yamanashi and ordered him to sound out the general opinion of the naval leadership. Meanwhile, military affairs adviser Admiral Okada Keisuke (who had previously served as navy minister under the previous Tanaka cabinet) had already been coordinating with Vice-Minister for Foreign Affairs Yoshida in an effort to bring the Naval General Staff on board. ${ }^{34}$

The Hamaguchi cabinet also received support from a group affiliated with the imperial court. This group included the elder statesman Saionji Kinmochi, who was then suffering from pneumonia, Lord Keeper of the Privy Seal Makino Nobuaki, Minister of the Imperial Household Ichiki Kitokurō, Grand Chamberlain Suzuki Kantarō, Deputy Grand 
Chamberlain Kawai Yahachi and Okabe Nagakage, who was concurrently serving as both chief secretary to the lord keeper of the privy seal and as deputy grand master of the ceremonies. At around this time, Castle wrote in his diary:

The London situation looks a lot better as between the Americans and the Japanese because the Japanese are apparently realizing that if the conference is to succeed they cannot have everything they want. ${ }^{35}$

Despite the progress that had been made, three problems remained. First, there was criticism from the Naval General Staff and from Fleet Admiral Tōgō Heihachirō. To deal with this criticism, Shidehara enlisted the support of Yamanashi, a fact that Castle learned from Yoshida. ${ }^{36}$

Second, there was the problem of the Japanese media. Of particular concern were articles that appeared in the evening editions of the Tokyo Asahi Shimbun and the Tokyo Nichinichi Shimbun on 17 March. These articles contained figures from the compromise proposal between Japan and the US that had been leaked by Vice Chief Suetsugu and were published alongside a dissenting opinion from the navy. This event greatly irritated Shidehara, Hamaguchi and the Japanese delegation. ${ }^{37}$

Third, France, which had proven difficult in its negotiations with the UK, attempted to avoid becoming isolated by arguing that Japan should not be permitted more submarines than it already had. There were also those in the delegation, such as Representative Takarabe, who thought that Japan ought to join forces with France and push back against the UK and the US. However, Shidehara and Wakatsuki reacted coldly to France's proposal. Shidehara did not want the conference to founder upon the submarine problem. This, too, was relayed to Castle by Yoshida. ${ }^{38}$

To try to bring the navy around, Shidehara enlisted the cooperation of the governor-general of Korea, Saitō Makoto, who had temporarily returned to Japan. Shidehara also took into consideration the opinion of Okada Keisuke. However, it was thought that a direct meeting between Shidehara and Saitō might be misinterpreted by others. For this reason, Shidehara sent Yoshida as a messenger, after receiving approval from Hamaguchi. Meanwhile, Stimson was increasingly irritated at the delay in any formal instructions from the Hamaguchi cabinet to the Japanese delegation. ${ }^{39}$ 


\section{‘A Silent Man’ - Prime Minister Hamaguchi}

On 20 March, having grown tired of waiting for a response, Stimson sought to push through the apparent impasse by asking Castle to seek a meeting with Prime Minister Hamaguchi. However, Castle was against seeking such a meeting. He understood that it might give the Japanese public the impression that the US was directly applying pressure on Japan.

As Castle puts it, Hamaguchi was 'a silent man' and not necessarily the sort of politician who could exercise leadership in such matters. Rather, Castle suggested that within the cabinet it was Shidehara who had more initiative, asking rhetorically: 'Could anyone be stronger than Shidehara has proven himself to be?' 40 Castle's proposal was for Hamaguchi to be awakened to the reality of the situation in London through Shidehara. To put it another way, for Castle, it was Shidehara who was ultimately the real negotiating partner. He did not have a high opinion of Prime Minister Hamaguchi. The British ambassador to Japan, John Tilley, had the same impression. The message from Prime Minister MacDonald to Hamaguchi was also entrusted to Shidehara, as Castle was aware. Similarly, Shidehara was also concerned that if Castle were to meet directly with Hamaguchi, it could lead to sensationalistic reporting in the Japanese media. ${ }^{41}$

There was another individual who concurred with Shidehara on the issue of Castle directly speaking with Hamaguchi. This was Yoshida Shigeru. Speaking with Castle, Yoshida agreed that it would have been most unwise to approach Hamaguchi'. ${ }^{42}$ Such a meeting, in his view, would only have furnished Japanese hardliners with an excuse to push their own agenda. In response to this feedback, Stimson began to change his stance. If Shidehara himself was against the idea, then he would not insist upon having his confidential message presented directly to Hamaguchi. On 24 March, Shidehara received a visit from Castle, who had come to discuss the message from Stimson to Hamaguchi. The message itself contained a great deal, including the argument that the US, the UK and Japan ought to cooperate with each other, given that they were the world's three great naval powers. As for how the message to Hamaguchi was to be handled, this Castle left entirely to Shidehara's discretion. The result was that Stimson's message was handed to Hamaguchi via Shidehara, as had taken place with the message from MacDonald. 
Shidehara was also kept informed of Castle's movements through Yoshida. For example, Yoshida informed Shidehara of a 23 March visit from Castle. At that time, to try to avoid the impression that the US was applying 'undue pressure', Castle had even sought to prevent Shidehara from passing Stimson's message on to Hamaguchi. ${ }^{43}$ On another occasion, Castle informed Yoshida through Secretary Dooman that Stimson was concerned about potentially inciting the Japanese public. Certainly, the US diplomats were being extremely cautious. Shidehara, of course, was aware of their concern. He himself took great pains with the handling of these messages.

Throughout this period of negotiations, Shidehara met numerous times with Hamaguchi. Finally, on 1 April, the Hamaguchi cabinet decided to respond to the Japanese delegation's request with instructions to accept the Japanese-American compromise proposal. Half a month had already passed since the delegation had sent its request. Prior to the cabinet meeting, Hamaguchi invited Military Affairs Adviser Okada, Naval General Staff Director Katō and Navy Vice-Minister Yamanashi to his residence. For an hour he attempted to bring them on board with respect to the delegation instruction draft, giving reasons for accepting the compromise from the perspectives of diplomacy and finance. Despite Hamaguchi's efforts, when Shidehara met with Castle after the issuing of the instructions, Castle interpreted this outcome as the result of Shidehara's efforts and sought to assist Shidehara further. In fact, since before the cabinet meeting, Castle had foreseen that the Hamaguchi cabinet would approve of the terms of agreement reached in London, thanks to information shared by ViceMinister Yoshida and Lord Keeper of the Privy Seal Makino. ${ }^{44}$

Meanwhile, from 31 March to 1 April, Naval General Staff Director Katō sought permission to issue a report to the throne. However, the report was delayed by Grand Chamberlain Suzuki Kantarō until 2 April. Nara Takeji, chief aide-de-camp to the emperor, was critical of Suzuki for this obstructionism, writing in his diary: 'I believe the grand chamberlain's actions were extremely improper'. ${ }^{45}$ On 1 April, Hamaguchi issued his report to the throne on the delegation instructions draft, which was then approved by the emperor.

On 2 April, Katō had an audience with the Shōwa emperor and presented the following report:

The proposal by the U.S. contains content that threatens to cause serious strategic ramifications for the Imperial Navy ... The adoption of the agreement proposed by the U.S. would require, 
for all intents and purposes, a reduction in military capacity as well as the ratio [of our forces relative to other nations], as argued for by the other imperial powers. Because this [reduction] would bring about serious changes to our strategic planning, based upon the national defense policy that was adopted in the 12th year of Taishō [1923], it is my belief that it requires serious deliberation. ${ }^{46}$

Although unaware of the specific details of the report, on 3 April, the Times stated that it contained a severe critique of the Japanese government.

However, while Naval General Staff Director Katō did present his report to the emperor on 2 April, it was not the case that he sought to prevent the acceptance of the agreement outright. The formal reason was that the Showa emperor had already approved the delegation instructions the previous day. Kato himself stated that the true motive of the report was 'only to have my concerns heard'. The emperor, too, 'was only of the opinion that he should at least hear [what I wished to say]'. Nara, chief aide-de-camp to the emperor, similarly wrote in his diary: 'As for the handling of this report to the emperor, even if it had been submitted prior to the issuing of the instructions, there was nothing to be done except to listen [to Katō's concerns]'. ${ }^{47}$ In other words, although it was a formal report, Katō, the emperor and Nara all felt that it should be treated only as an opinion to be taken into consideration. ${ }^{48}$ Even so, Katō ought to have received support by Vice Chief Suetsugu. Yet Suetsugu's imprudent behaviour was counterproductive in this regard. ${ }^{49}$

On 13 April, a luncheon party was held at the Imperial Palace. The Shōwa emperor had invited British Ambassador Tilley, with Shidehara and Prince Takamatsu Nobuhito also attending. The task of interpreting for the emperor fell to Sawada Renzō, director of the Telegraph Division. While the luncheon party was being held prior to Prince Takamatsu's planned visit to Europe, the discussion also ranged over the London Naval Conference. It was here that the Shōwa emperor addressed Ambassador Tilley with the following words:

Incidentally, on the topic of the Naval Disarmament Conference that is presently taking place in London, I am extremely pleased to hear that a satisfactory result may now be anticipated, thanks to the cooperation of the three nations of Japan, the U.K., and the U.S. ... Along with the success of this conference, it is also my hope that cooperation among the participatory nations, and in particular between Japan, the U.K., and the U.S., will help to further the advancement of world peace. ${ }^{50}$ 
In front of both Shidehara and Prince Takamatsu, the emperor expressed his pleasure that negotiations at the London Naval Conference appeared to be concluding with a compromise agreement. Understandably, Sawada was nervous interpreting the emperor's words on this occasion. Although the Japanese delegation had already received instructions from the Hamaguchi cabinet to accept the Japanese-American compromise agreement, the treaty had yet to be signed in London. There were also disquieting moves being made by the navy and the Seiyūkai. Given the delicate nature of the situation, which was after the issuing of the instructions but before the signing of the final treaty, it may well have been better if the emperor's statement was more reserved. Although Sawada was unsure whether to interpret everything the emperor was saying, he was effectively left with no choice but to render his words into English.

Pleased with the emperor's comment, Tilley stated that he would relay it to London. The manner in which the emperor expressed his thoughts on this occasion was therefore fully capable of leading to unforeseen events. That being said, Shidehara, who, as noted above, was also in attendance, was not overly nervous about the possible ramifications of the emperor's statement. Moreover, when he returned to the Ministry of Foreign Affairs, he attempted himself to relay the details of the emperor's comment to the Japanese delegation. Although the emperor had already granted his approval of the delegation instructions, Shidehara's actions on this occasion appear to have been somewhat careless. It was Yoshida who realised the possible danger. Taking into account the wishes of Ichiki, the minister of the imperial household, he made his own addition to Shidehara's telegram: 'Request that particular care be taken to prevent this news leaking to the newspapers, etc. ${ }^{51}$ Yoshida was aware that the emperor's words, if leaked, would have a massive impact.

\section{Shidehara's Diet Address and Castle's Departure}

In the end, the London Naval Treaty on Disarmament was formally signed on 22 April. ${ }^{52}$ Right afterwards, the 58th Imperial Diet commenced in Japan. This Diet would soon become the setting for an unfolding debate regarding the problem of supposed supreme command interference. Article 11 of the Meiji Constitution stipulates that supreme command over the navy rests with the emperor and not with the ministers of state. On the other hand, Article 12 states that supreme power over military organisation is a state affair to be determined by the advice of the cabinet. 
At the convening of the House of Representatives on 25 April, Shidehara made an address directly after Prime Minister Hamaguchi. He stated: 'Through a comparative analysis of the various positives and negatives for the empire [Japan], we have confirmed that it is absolutely advisable to participate in this agreement'. Shidehara was immediately showered with criticism from the attending members of the Seiyukai opposition. The president of the Seiyūkai, Inukai Tsuyoshi, then responded with a counterargument based upon a declaration by Naval General Staff Director Katō. In the same fashion, Hatoyama Ichirō aligned himself with the Naval General Staff, angrily arguing: 'I believe that Foreign Minister Shidehara's position is entirely that of an administrator and not the serious argument of a politician. (Applause.)'53

From today's perspective, we may find it hard to fault Shidehara's address. It cannot be denied, however, that, given the circumstances at the time, Shidehara did not show sufficient concern for how the opposition and the navy would react. In his diary, Naval General Staff Director Katō wrote that 'Shidehara's speech on diplomacy was nothing but a spewing of groundless arguments; the government and the people are in an uproar'. ${ }^{54}$ Although Shidehara thought he had received the navy's support through discussions with Vice-Minister Yamanashi, Yamanashi was perplexed by Shidehara's speech. Even if only to some degree, there was a need for suitable comments to be directed at the nation. Beyond that, there was the problem of the Seiyūkai's policy. Although the Diet had no authority over ratification, their reaction posed a threat to the foundation of party politics; the authority for ratification rested with the Privy Council. ${ }^{55}$ That said, while the manner in which the Seiyūkai and the navy reacted to the London Naval Treaty is typically viewed as problematic, that does not mean that they had the same stance. For example, as noted earlier, though it is true that Naval General Staff Director Katō presented a dissenting view in his 2 April report to the emperor, he did not actively seek to overturn the acceptance of the compromise agreement.

Even more so than Shidehara, it was Castle who had demonstrated the most caution when it came to the Diet and Japanese public opinion. Throughout the month of May, Castle went on a speaking tour of several Japanese cities, including Kyoto, Osaka, Kobe, Nagoya, Nara and Nikkō. For Castle's speech at Osaka, Shidehara gave him permission beforehand to mention some of the details of the London Naval Conference. ${ }^{56}$ Castle, who handled the media shrewdly, later boasted that his speeches helped to hasten Japan's ratification of the London Naval Treaty. Shidehara himself acknowledged this fact. As Castle would later recall: 
The press was waiting, and the Navy was waiting for me to make the break of going over Shidehara to Hamaguchi or for me to make some public utterance that might be interpreted as bringing pressure to bear. $^{57}$

For this reason, Castle was careful until the very end to always restrict himself to dealing with Shidehara and Yoshida.

It should be noted that, to begin with, it was on the occasion of the London Naval Conference that Castle was dispatched to Japan. Indeed, he had to return to the US after concluding his speeches in the various regions of Japan, even though this was still before Japan's final ratification of the London Naval Treaty. Along with the ratification of the treaty, there was one more matter that Castle was apprehensive about. Division of Far Eastern Affairs Chief Hornbeck had engaged in negotiations, albeit unofficial ones, with China's minister to the US, Wu Chaoshu, over the termination of extraterritorial rights in China. Shidehara, however, believed that Japan, the US and the UK ought to engage in coordinated negotiations with China, in Nanjing. Castle was sympathetic towards Shidehara's view and told Stimson he was concerned about Hornbeck overstepping on this matter. ${ }^{58}$

With Castle's scheduled return to the US drawing closer, Tani Masayuki, First Division director of the Asian Bureau at the Ministry of Foreign Affairs, assumed that Shidehara and Castle would have a final opportunity to meet. On 20 May, he drafted a proposal for Shidehara's use of topics to discuss in that final meeting. Tani wrote:

As your ambassador was recently proclaiming, with respect to the policies towards China of Japan and the U.S., and the principle advocated by your ambassador of mutual prosperity through commerce, not only are [these policies] not opposed, they are actually entirely congruent. ${ }^{59}$

Upon receiving a copy of this draft, Asian Bureau Director-General Arita Hachirō made the following addition on the same day:

Among officials and the people of some foreign nations, there are those who have misunderstandings regarding the problem of Japan's 'competitive lines' in Manchuria, believing that the South Manchuria Railway Company seeks to exclusively dominate all of Manchuria. ${ }^{60}$ 
Arita was attempting, through Shidehara, to gain Castle's understanding with respect to Japanese policy on the South Manchuria Railway. However, although Shidehara was aware of the Asian Bureau's opinion, he did not seek to emphasise this point during his meeting with Castle. It would seem that, when it came to Castle at least, Shidehara had judged him as already recognising Japan's initiative in matters of Chinese policy. We also know that Castle himself wanted to avoid directly touching upon Manchurian policy, given its controversial nature. ${ }^{61}$

On the occasion of Castle leaving his posting in Japan, the AmericaJapan Society hosted a dinner party on 23 May. Along with Shidehara and Yoshida, the dinner party was attended by Tokugawa Iesato, Chairman of the America-Japan Society and President of the House of Peers, and Hanihara Masanao, former ambassador to the US. In his address to the gathering, Castle spoke of the coming period following the conclusion of the London Naval Treaty. The US, he argued, needed to learn that 'Japan must be and will be the guardian of peace in the Pacific'. ${ }^{62}$

On the Japanese side, following Tokugawa, Hanihara began to read an address. He unexpectedly mentioned the Japanese Exclusion Act, arguing for the need of a 'renewal of friendship'. ${ }^{63}$ This comment left Castle feeling ill at ease. Upon hearing of this incident, British Ambassador Tilley spoke with Yoshida, asking half-jokingly if Hanihara's speech had been suggested by the Ministry of Foreign Affairs. Yoshida replied that, during Hanihara's speech, both he and Shidehara were so uncomfortable that they did not even know where to look. ${ }^{64}$

Although the Japanese Exclusion Act Hanihara mentioned had been overshadowed by the proceedings of the disarmament conference, even in the US calls for its revision were growing stronger. Shidehara had been informed of this fact by ministry officials in the field. As one example, when president of Columbia University Nicholas Murray Butler invited Sawada Setsuzō, Japanese consul general in New York, to a luncheon, he responded positively to the idea of revising the immigration act. Similarly, MacMurray-who had resigned from his post as the US minister to China and taken up a position at Johns Hopkins University as the director of the Walter Hines Page School of International Relations-had discussed the Japanese Exclusion Act in a speech. ${ }^{65}$ 


\section{The Japanese Exclusion Act Amendment Problem and Policy on China}

In July 1930, following his return to the US, Castle was once more appointed assistant secretary of state. ${ }^{66}$ William Cameron Forbes, Castle's replacement as the US ambassador to Japan, had previously served as governor-general of the Philippines. Shidehara was initially informed about Forbes through private correspondence from Castle, who mentioned that Forbes was a prominent Western expert on East Asia. As well as stating that he welcomed Forbes's appointment, Shidehara indicated that he appreciated the US government's position on reforming the Japanese Exclusion Act. It was best, he wrote, to avoid being overly hasty with such matters. ${ }^{67}$

In correspondence addressed to Forbes, Castle also wrote that Tokyo was a first-rate city, equal to London. He also took pains to offer advice to Forbes, who was then 60 years old and single, including on local living conditions. Following his return to the US, Castle did not neglect in his speeches to promote the importance of fostering goodwill between Japan and the US. ${ }^{68}$ It may well have been that Castle's concerns over the US embassy in Japan were groundless. On this topic, further details can be found in the written recollections of Sir George Sansom, who resided long-term in Japan while serving as commercial counsellor at the British embassy. According to Sansom, 'the American embassy always had one or two very good counsellors like Edwin Neville. ${ }^{69}$ Sansom noted that Neville had developed friendships with many Japanese during his time in Japan and that Sansom's own close friend Dooman, the first secretary at the US embassy, was also talented. Finance Minister Inoue, who was an old acquaintance of Forbes's from his time as governor-general of the Philippines, also welcomed his posting as ambassador.

Another notable incident occurred on 10 June, when Naval General Staff Director Katō submitted his resignation to the emperor. Despite such protests, the London Naval Treaty was ratified on 2 October, following deliberation by the Privy Council. Shidehara had been waiting impatiently for this day, and it was to him that Castle immediately dispatched a letter once he learned of the result. ${ }^{70}$ On the other hand, Debuchi, who was still serving as ambassador to the US, attempted to turn the ratification of the London Naval Treaty into an opportunity to reform the Japanese Exclusion Act. Secretary of State Stimson, who spoke with Debuchi on 
the topic on 30 October, agreed to the idea of Debuchi and Castle holding secret talks on the immigration act, an indication of his enthusiasm for the further improvement of Japanese-American relations. ${ }^{71}$

Shidehara and Castle acknowledged that resolving the issue of naval disarmament had helped improve relations between Japan and the US. At the same time, however, they believed that any sudden attempt to move forward with Japan's keenly desired reform of the Japanese Exclusion Act could backfire. For this reason, they viewed Debuchi's more insistent attempts at seeking a revision of the act as rash. ${ }^{72}$

Along with the matter of revising the Japanese Exclusion Act, an outstanding issue for Japan and the US was policy on China. Shidehara, as noted above, thought that the problem of extraterritorial rights in China should be handled through negotiations conducted in Nanjing, with Japan, the US and the UK jointly coordinating their efforts. Castle similarly argued in favour of cooperation between Japan and the US on this matter, bringing him into opposition with Hornbeck, chief of the State Department's Division of Far Eastern Affairs, who was more sympathetic toward China. Hornbeck frequently received private correspondence from Johnson, US minister to China. This placed him in the unique position of knowing what was going on inside China, including the movements of individuals such as British Minister Miles Lampson. ${ }^{73}$ China hands such as Hornbeck and Johnson did not express interest in tying the success of the London Naval Conference to the matter of Japanese-American cooperation in China. While Stimson showed a degree of sympathy to Debuchi with respect to the immigration problem, when it came to policy on China, he was unable to overlook the advice and information from figures such as Hornbeck. ${ }^{74}$

As can be seen, Castle paid careful attention not only to how the press covered the London Naval Treaty but also to matters such as his successor, the immigration problem and policy on China. Thanks in part to Castle's efforts, the relationship between Japan and the US had begun to improve. Unfortunately, the situation soon worsened, and the cause was Shidehara himself. In November 1930, Prime Minister Hamaguchi was shot and badly wounded at Tokyo Station. This meant that Shidehara became acting prime minister. Then, in February 1931, he would misspeak during the 59th Diet, triggering an uproar. 
The specific occasion was a meeting of the House of Representatives budget committee on 3 February. Nakajima Chikuhei of the Seiyūkai had asked some questions about naval disarmament. Because Navy Minister Abo Kiyokazu was absent due to sickness, initially these questions were answered by Yabuki Shōzō, parliamentary vice-minister for the navy. When Nakajima inquired about responsibility for 'causing our national defenses to be insufficient', Shidehara responded with the following ill-advised words: 'Given that it has now been ratified [by the emperor], it is clearly the case that the London Naval Treaty has not put our national defense into any danger'. The committee responded uproariously, with jeers to the effect of: 'What is the meaning of making it the emperor's responsibility? ${ }^{75}$ Further discussion was impossible. Even Committee Chief Takeuchi Sakuhei was unable to get the committee to reconvene the following day.

Shidehara meant to point out that the navy minister had also attended the military counsellor meeting and added his signature to the petition to the emperor requesting that the treaty be ratified. Therefore, it hardly made sense to speak of supreme command interference. And indeed, his response continued with the following justification:

In saying that [the treaty] received ratification, [what I mean is that] it is entirely the government's responsibility. I do not seek to absolve myself of this responsibility in the slightest. At the same time, when the ratification petition to the emperor was sent. ${ }^{76}$

Yet Shidehara's voice was drowned out by the angry roar of the committee.

Judging from the committee minutes, it cannot be denied that Shidehara's response to Nakajima's line of questioning was careless. Reflecting upon this incident in later years, Shidehara suggested that the uproar was in fact orchestrated by Mori Tsutomu, secretary-general of the Seiyūkai. Castle must have surely been disturbed to learn of Shidehara's difficulties via sources such as the correspondence he received from Nitobe Inazō. ${ }^{77}$

\section{The Limits of Japan-US Cooperation}

So far in this chapter, I have provided an outline of both Shidehara's actions and Japanese-American relations during the period of the London Naval Conference. I will now expand upon this initial picture with some further details, while also considering the reality and the limits of JapanUS cooperation at this time. If asked to think of a party-based cabinet 
in modern Japan that attempted to carry out cooperative diplomacy between Japan and the US, most would probably name the cabinet of Hara Takashi. However, although the Hara cabinet was supposed to be the first fundamentally party-based cabinet, it was not highly regarded by the Wilson administration. ${ }^{78}$ In fact, it was in the period of the London Naval Conference when party-cabinet-based cooperation with the US was at its most mature, as well as when there were those on the US side who sought to reach out as potential partners. At the centre of these efforts at cooperative diplomacy were Shidehara and Castle.

That said, from Castle's perspective, it was not the Minseitō that had taken the initiative of guiding cooperation between the two nations. Rather, it was Shidehara who Castle considered to be leading such efforts. His estimation of the man in this regard was close to overwhelming praise. In correspondence sent to President Hoover following the Hamaguchi cabinet's issuing of instructions to the Japanese delegation, the only Japanese individual Castle specifically named as deserving of merit was Shidehara, stating that he was the leader of those who sought closer cooperation with the US. Castle understood his own responsibility to be that of 'creating a friendly atmosphere' in a nation that he saw as of particular importance for the US. As he also wrote in a letter to Hoover: 'I cannot help feeling that London, Tokyo and Mexico are our three most critical posts'. ${ }^{79}$

As noted earlier, Shidehara and Castle saw eye to eye not only on the London Naval Treaty but also regarding policy on China, such as the matter of extraterritorial rights. ${ }^{80}$ Castle was quick to discern that the 'China problem' was not unconnected to the issue of naval disarmament. Therefore, in seeking to have Japan's leadership recognised regarding the China problem, Castle was, at the same time, attempting to help guide the London Naval Conference to a successful conclusion. In reality, the Naval General Staff, beginning with Katō Hiroharu, had been arguing for some time that one of the reasons they could not compromise on naval disarmament was that they wanted to forestall US pressure on Japan's policies regarding China. A similar opinion was expressed by the Privy Council's London Naval Treaty Judging Committee. Committee member Kawai Misao, for example, was concerned about the US becoming emboldened in its regional diplomatic efforts. Pressing Hamaguchi on the topic, he once asserted that 'Japan has to militarily prepare with the China problem in mind'. ${ }^{81}$ 
It was Yoshida, meanwhile, who served as mediator between Shidehara and Castle so well. This is a bit surprising, given that Shidehara and Yoshida had differing views when it came to policy on China. In terms of personality as well, Yoshida found Tanaka, the previous foreign minister, to be easier to work for, due to his 'generous temperament'. By contrast, he was not fond of the 'stubbornly precise' Shidehara. According to Yoshida, Shidehara's obsession with the minutiae of ministry work was such that he could not stand to delegate tasks to the vice-minister as needed. Such behaviour, in his opinion, showed that Shidehara was not cut out to be the foreign minister. Given that Shidehara spent so much of his time holed up in the ministry, it often fell to Yoshida himself to take care of public relations. In doing so, he was able to make up for some of the shortcomings of Shidehara, the 'discreet worker'. ${ }^{82}$ This dynamic was probably what inspired the running joke in the ministry that Shidehara was the vice-minister and Yoshida was the minister. Yoshida also took responsibility for sharing ministry information with certain key figures. For example, during one period he delivered summaries of discussions that were being held between Shidehara and China's minister to Japan, Wang Rongbao, to his father-in-law, the lord keeper of the privy seal, Makino Nobuaki. ${ }^{83}$

Castle's estimation of Makino was also extremely high. Indeed, Makino's shrewdness was one of the reasons he had long been trusted as the emperor's go-between. This kind of evaluation of Makino was not necessarily unreasonable, particularly given that Shidehara felt comfortable in providing him with top-secret documents from the navy and the Ministry of Foreign Affairs. ${ }^{84}$ On the other hand, aside from concerning Hamaguchi's performance alongside Home Minister Adachi Kenzō in leading the Minseitō to electoral victory, Castle's opinion of Hamaguchi was not high. ${ }^{85}$ Of course, the reason why Castle avoided directly negotiating with Hamaguchi was that he was wary of giving the impression that he was applying outside pressure on behalf of the US. Given that even in London the important negotiations between Japan and the US were unofficial, it was surely wise that Castle avoided negotiating with Hamaguchi. Shidehara had also been opposed to any direct discussions between Hamaguchi and Castle.

However, the more fundamental reason was that Castle had higher expectations of Foreign Ministry officials such as Shidehara and Yoshida than of the leaders of the ruling party. And indeed, Shidehara more than lived up to those expectations. From Castle's perspective, the role of the 
party politicians headed by Hamaguchi was not of primary importance. Hamaguchi's sheer determination to steer a meeting to a consensus, even at the risk of his own life, ${ }^{86}$ was apparently a quality that the staff at the US embassy were not sufficiently aware of. In considering the nature of Japanese politics during the period in question, it is illuminating that the US ambassador held Makino in higher esteem than Hamaguchi. Further, Castle did not have contact with Nagai Ryūtarō, who supported Shidehara from within the Minseitō party, as parliamentary vice-minister for foreign affairs. ${ }^{87}$ Evidently, as far as foreign affairs was concerned, the US embassy did not view Japanese party politics as mature.

When Castle sought to have his thinking communicated with the Japanese navy, a common path of transmission was from Shidehara to Navy ViceMinister Yamanashi. Shidehara's English proficiency was invaluable in this regard. In fact, the closeness of Shidehara and Castle was such that it became a matter of concern for Naval General Staff Director Katō. ${ }^{88}$ That Castle developed such a positive relationship with Shidehara following his dispatch to Japan for the period of the London Naval Conference was in itself quite significant. At that time, the US ambassador to Japan was generally thought to be of little importance, even compared to the minister to China. ${ }^{89}$ It was rare for officials at the rank of undersecretary of state to have the experience of actually residing in Japan.

It was also during this period that officials more familiar with Japan, such as Secretary Dooman, began to work at the US embassy. This development would also have helped bring the two nations closer together. ${ }^{90}$ Along with Dooman, another figure who was viewed as representative of a new generation of Japan was the State Department official Joseph W. Ballantine. Returning home after the London Naval Conference, Ballantine's choice for his next posting was not Japan but Guangdong, as consul general. Given that Ballantine had tended to be biased in favour of Japan at that point, this experience would have surely expanded his perspective. ${ }^{91}$

This is all to say that the relationship between Japan and the US in the modern period more or less reached its peak during the period of the London Naval Conference. On the Japanese side, there was Shidehara, a foreign minister who acted as a driving force for positive relations from the time of the conference. Then there was also Debuchi, Shidehara's subordinate and close confidant, who would go on to serve as ambassador to the US. In the US State Department, meanwhile, a pro-Japan clique was forming. Castle's appearance in the annals of US diplomacy can be 
seen as continuing down a path blazed by MacMurray, previous minister to China and chief of the State Department's Division of Far Eastern Affairs. After returning to the US, Castle initially served as assistant secretary of state from July 1930 to April 1931. He would subsequently become undersecretary of state, from April 1931 to March $1933 .^{92}$ While Japan-US relations were at their best in this era, this situation was not sustainable.

Certainly, the naval disarmament talks were not unconnected to the 'China problem' or to the immigration problem. Their successful conclusion, therefore, at the same time indicated that it was possible for a more secure regional order to arise in East Asia. Hence, we see, for example, figures such as Debuchi pushing quite strongly for a revision to the Japanese Exclusion Act, and Secretary of State Stimson showing his willingness to work on this issue. However, as they were familiar with the situation on the ground, Shidehara and Castle considered it overly hasty to tie the success of the London Naval Conference directly to the Japanese Exclusion Act reform. Instead, they were concerned about the possibility of a backlash. They did not think that the construction of a new order through Japan-US cooperation, including on immigration and China, could be realised so quickly. After all, while Castle was favourable to Japan, his perspective was not representative of US mainstream thought. The idea that China policy ought to be tied to the success of naval disarmament talks was a difficult sell to China hands such as Division of Far Eastern Affairs Chief Hornbeck, or Johnson, the US minister to China.

Stimson too, though sympathetic to the need to revise the Japanese Exclusion Act, could hardly ignore the wishes of the China hands in his department when it came to policy on China. This area may well have become a barrier to the development of a new international order, which was in turn essential to Japan-US relations. On this matter we have corroboration from Sansom, who was a commercial counsellor at the British Embassy in Japan. In his reminiscences on the period, he stated: 'The State Department and the American Government over-emphasised the importance and also the virtues of the Chinese'. ${ }^{93}$ In his view, the State Department and the government ought to have paid greater heed to those officials who were more familiar with Japan.

The isolation of the pro-Japan faction in the State Department did not greatly improve in the subsequent period, when Joseph C. Grew served as ambassador to Japan. According to the recollections of Embassy First 
Secretary Dooman, Hornbeck was eager to deny the wishes of Grew and Dooman. Understanding that it was hopeless, they apparently lost the motivation to even bother writing private correspondence to Hornbeck or his subordinates. ${ }^{94}$ All this is to say that, given subsequent events, the London Naval Conference on Disarmament was undeniably not only a high point but also a turning point. ${ }^{95}$ Matters deteriorated from then on. When looking at the problem of military disarmament, it is easy to pay too much attention to the ratios allotted to each nation that limited their naval forces. In reality, such ratios by no means guarantee that peace will prevail. Of far greater importance is the foundation of such disarmament treaties: the potential for the steady cultivation of a relationship of trust. Though it was over 90 years ago, Shidehara and Castle's friendship still provides this message to us today.

\section{The Manchurian Incident}

\section{The Hamaguchi Shooting Incident: Assuming the Role of Acting Prime Minister}

In December 1930, following the ratification of the London Naval Treaty, Shidehara replaced Yoshida Shigeru with Nagai Matsuzō as vice-minister for foreign affairs. Previously, when Shidehara served as vice-minister, Nagai was director of the Telegraph Division. Together, they would frequently work late into the night. Since that time, Nagai had progressed through the positions of International Trade Bureau director-general, minister to Sweden and ambassador to Belgium. During the London Naval Conference on Disarmament, he served as one of the plenipotentiary representatives in the Japanese delegation. It should be noted that his appointment as ambassador to Belgium in April 1928 was the wish of Vice-Minister Debuchi. Under the Meiji Constitution, ambassadors and vice-ministers were ranked as 'shinninkan' (officials appointed by the emperor) and 'chokuninkan' (imperial appointees), respectively. In other words, ambassadors actually ranked higher than vice-ministers. This meant that when Nagai became vice-minister after serving as ambassador to Belgium, he was technically being demoted. Nevertheless, Shidehara wanted his old acquaintance to take on the role. ${ }^{96}$ 
Shortly before this staffing change, Shidehara had also requested that the ambassador to Italy, Matsuda Michikazu, serve as director-general of the Treaties and Conventions Bureau. Such personnel choices were certainly unusual. Yet, in this way, Shidehara was able to reinforce the ministry with the capable figures of Vice-Minister Nagai and Treaties and Conventions Bureau Director-General Matsuda. As a diplomat wrote:

The army and the navy seemed quite displeased by these personnel changes ... What was the Ministry of Foreign Affairs planning by having three generals (shinninkan) at once? Were they seeking to gain leverage to push back against the San-Chokan [Three Chiefs] in the Army? There were people making jokes of this nature. ${ }^{97}$

The 'San-Chokan in the Army' referred to here were the war minister, the chief of army general staff and the inspector general of military training.

Shidehara was extremely busy during this period. As indicated earlier, this was because he was serving as the acting prime minister. According to Shidehara:

I will never forget it. It was the fifth year of Shōwa [1930], November 14. That was the day that Prime Minister Hamaguchi was shot by an assassin at Tokyo Station. ${ }^{98}$

On the day in question, Shidehara had been standing on a platform at Tokyo Station. He had come to see off Hirota Kōki, who was departing to take his position as ambassador to the Soviet Union. Coincidentally, Prime Minister Hamaguchi appeared at the same time. He was headed for Okayama, where he intended to observe military exercises.

The next moment, Shidehara heard a gunshot. A right-wing youth had shot Hamaguchi. In shock, Shidehara pushed through the gathering crowd and found Hamaguchi bloodstained and gravely wounded. In a strained voice, Hamaguchi reportedly said: 'Danshi no Honkai da'. Translated literally, this means 'a man's long-cherished desire'. What Hamaguchi meant was: 'I have served my country'. Struggling, Hamaguchi then added, with a groan: 'I dealt with the cabinet meeting for the budget draft yesterday, so this is good timing'. Shidehara replied, looking into Hamaguchi's face: 'If you keep talking, you'll only lose more blood, so be quiet now'. ${ }^{99}$ The assailant's motive was opposition to the naval disarmament treaty. Apparently, the assassination plans had also included Shidehara as a target. As a result of the Hamaguchi Shooting Incident, Shidehara became acting prime minister. 
Recommending Shidehara for the position of acting prime minister were the minister for railways, Egi Tasuku, and House of Peers member Izawa Takio. As Shidehara himself had no ambition for high political office, it was relatively easy to secure sufficient support for him to serve as acting prime minister. As he said: 'I merely took on the position temporarily'. ${ }^{100}$ Yet, desired or not, Shidehara's appointment as acting prime minister was actually a disaster for his friend Hamaguchi. As mentioned above, in February 1931, Shidehara misspoke at a committee meeting during the Diet. Following this incident, in March, he was relieved of his position as acting prime minister. The problem was that there was no government mechanism allowing an acting prime minister to be replaced by another acting prime minister. The result was that Hamaguchi himself was forced to attend the House sessions as prime minister. As he began to attend the House sessions, Hamaguchi's condition soon deteriorated. At the time, Hamaguchi sought Shidehara's opinion on who should succeed him as president of the Minseitō. When Shidehara said that 'Wakatsuki would be a suitable choice', Hamaguchi replied: 'I agree entirely'. ${ }^{101}$

Thus, former prime minister Wakatsuki was chosen as the next Minseitō president. When the Hamaguchi cabinet resigned en masse in April 1931, the emperor instructed Wakatsuki to form his second cabinet. Naturally, Shidehara resumed his post as foreign minister. However, Hamaguchi's condition grew worse. He finally passed away on 26 August, aged 61. It was late summer, and a mere three weeks before the Manchurian Incident. If it were not for the shooting at Tokyo Station that Shidehara witnessed, the cabinet led by his old friend Hamaguchi might well have become the longest administration since the Hara cabinet. Further, if Hamaguchi, known as the 'lion prime minister', had still been in charge, the days following the Manchurian Incident might well have unfolded quite differently. For Shidehara, it was undoubtedly a heartbreaking loss.

As if this were not enough, Shidehara also had another problem on his hands at this time: the 'Black Chamber'. The Black Chamber was the name given to the US government's secret decoding room. There the diplomatic telegrams of various foreign nations were decoded in huge quantities. This included the diplomatic telegrams of Japan, which the US had been intercepting since before the Washington Naval Conference. The central figure in this effort was a man named Herbert O. Yardley. 
Yardley's Black Chamber, however, was eventually abolished by Secretary of State Stimson. Displeased with this decision, Yardley would go on to publish a tell-all book on the decoding project, titled The American Black Chamber. Shidehara learned of this book in June 1931, through Ambassador Debuchi. The book apparently had many pages on Japan. The details of this project would subsequently become known throughout the world. The Japanese press, of course, was hardly likely to overlook such a story. The Osaka Mainichi Shimbun company quickly had it translated into Japanese and published it in August 1931 with the title The Black Chamber: Beikoku wa Ikanishite Gaikö Hiden wo Nusundaka (How did the US steal the secret diplomatic telegrams?). Although Shidehara worked out a plan for handling the Diet and issued warnings to Japan's overseas diplomatic establishments, the damage was done. ${ }^{102}$

\section{The Manchurian Incident and Discussions with Stimson}

Let us now turn to the matter of Japan's relationship with China. March 1930 saw the initial signing of the Sino-Japanese Tariff Agreement. With this agreement, Japan recognised China's tariff autonomy. At this time, the Hamaguchi cabinet also passed a resolution to change how China was formally referred to in official documents. Rather than simply 'China'-or, rather, the old equivalent, which was 'Shina' (支那) in Japanese-China would now be referred to as the 'Republic of China' (中華民国). ${ }^{103}$ The Chinese government had criticised Japan's original designation of 'Shina', and the Hamaguchi cabinet decision was a response to that criticism.

With the matter of tariffs resolved, the focus of attention subsequently shifted to the termination of Japan's extraterritorial rights in China, and the refinancing of foreign loans. Concerning Japan's relationship with China, Shidehara gave a speech on national radio in which he argued: 'We are determined to do our utmost in working toward the goal of reciprocal benefit, that is to say, so-called prosperous co-existence'. ${ }^{104}$ When it came to negotiations with China, however, Shidehara was hardly free to take the lead himself. Given the London Naval Conference on Disarmament and, later, his work as acting prime minister, Shidehara was buried in paperwork. He therefore delegated work in this area to Shigemitsu, the acting minister to China. Shigemitsu proceeded with the negotiations with an eye towards promoting greater cooperation between the two 
nations. He also went a step further and attempted to push Shidehara towards promoting Sino-Japanese partnership. Shidehara, however, did not acquiesce. As in the past, he continued to put far more emphasis on Japan's relationship with the US and the UK. He was also gradually moving beyond the economism that he once adhered to so strongly. Ironically, it was not until the Manchurian Incident that Shidehara's and Shigemitsu's positions began to converge. ${ }^{105}$

On the evening of 18 September 1931, the Kwantung Army (a division of the Japanese Imperial Army stationed in Kwantung) detonated a bomb that they set on a line of the South Manchuria Railway, near Liutiaohu on the outskirts of Shenyang. Blaming this explosion on the Chinese, the Kwantung Army then used the incident as a pretence for mobilisation. This conspiracy, which is also known as the Liutiaohu Incident, was the beginning of the Manchurian Incident. The core figures in this conspiracy were Ishiwara Kanji and Itagaki Seishirō of the Kwantung Army. Before the Liutiaohu Incident, Shidehara perceived signs of a plot by members of the Kwantung Army, thanks to telegrams from Hayashi Kyūjirō, consul general in Mukden. ${ }^{106}$

On 19 September, the day after the Liutiaohu Incident, numerous pieces of information gathered by the Ministry of Foreign Affairs were read aloud at a meeting of the Wakatsuki cabinet. This information included details such as how, before the explosion, the Fushun Independent Garrison had asked the South Manchuria Railway to prepare a train carriage for transport. Similarly, the General Headquarters of the Kwantung Army had also been preparing for mobilisation before the explosion. Thus, Shidehara was able to state that 'this incident almost appears as though it occurred as a result of planning by the military'. ${ }^{107}$ For this reason, War Minister Minami Jirō was unable to secure a cabinet agreement that day to send reinforcements from the Japanese Korean Army. Instead, the Wakatsuki cabinet decided that the incident needed to be contained. The US likewise hoped that Shidehara would work to prevent any escalation.

The cabinet's wishes, however, were soon frustrated. On 21 September, the Kwantung Army moved into Jilin, and the Japanese Korean Army, led by Commander Hayashi Senjūro, crossed the border into Manchuria without orders. The following day, the cabinet voted to authorise the expense request sent by the Japanese Korean Army. On the Japanese Korean Army's unauthorised crossing of the border, Prime Minister Wakatsuki stated indifferently: 'Now that it has happened, I suppose it 
simply cannot be helped'. ${ }^{108}$ On 8 October, the Kwantung Army bombed the city of Jinzhou, which was far away from the South Manchuria Railway line. The actions of the Japanese army were now expanding throughout the broader Manchuria region. When the Manchurian Incident erupted, Shidehara's basic thinking was that direct negotiations were necessary between Japan and China. He wished to avoid having any of the Western nations act as mediators.

On 9 October, the Wakatsuki cabinet agreed upon a new policy of withdrawing troops following the reaching of a general agreement with China on matters such as the prohibition of boycotting Japanese goods, and the signing of a Sino-Japanese railway agreement. While China had asserted that a troop withdrawal was a precondition for any negotiations, Japan decided it would withdraw only if its conditions were met through direct negotiation. The Nationalist government, however, appealed to the League of Nations over the Manchurian Incident, and resolved not to negotiate directly with Japan under the given circumstances. Chiang Kai-shek even sent a request to Zhang Xueliang, asking him not to begin any such negotiations.

At the end of November, V. K. Wellington Koo (Gu Weijun), who had taken the position of foreign minister for the Nationalist government, informed the UK, the US and France of a plan to establish a neutral zone around Jinzhou. Jinzhou, located in south-western Liaoning province, had become the base of operations for the government of Zhang Xueliang after he was ousted from Shenyang. Wellington Koo's proposal was for the Jinzhou region to be demilitarised and to be monitored by the other powers, so as to prevent any further conflict between Japanese and Chinese forces. At the same time, this plan can be seen as a signal for opening up negotiations with Japan. Wellington Koo had previously engaged Shidehara in debate at the Washington Naval Conference and had hopes that he would assist with his plan to prevent further conflict. This development increased the possibility of direct negotiations between Japan and China.

At the beginning of December, Shidehara also began to push Zhang Xueliang to accept the demilitarisation of Jinzhou. However, Shidehara sought not only to have the Chinese army withdraw but also to have the government of Zhang Xueliang withdraw west past Shanhaiguan. Chiang 
Kai-shek and Zhang Xueliang would hardly accept such a request. Thus, it was not surprising that direct negotiations between Japan and China did not resolve the crisis.

Following this failure, Shidehara began to acquiesce to the idea of establishing a puppet government in north-eastern China led by the Japanese army. In mid-November, a fierce debate had broken out between War Minister Minami, who argued for an attack on Qiqihar city in Heilongjiang province, and Shidehara and Wakatsuki, who objected to such an idea. The agreement that was eventually reached was for a puppet government to be established in Qiqihar, with a subsequent withdrawal of Japanese troops. This was the moment when Shidehara compromised on the idea of a military-led puppet state. Thereafter, Shidehara gradually distanced himself from the ideal of the military being regulated by international cooperation. Increasingly, he acquiesced to the military having control over policy in China. With the style of Shidehara diplomacy in part disintegrating, in part metamorphosing, it can be said that the end of the Washington System of regional order in East Asia was instigated by the Japanese side. ${ }^{109}$

The Manchurian Incident would have serious implications for Japan's relationship with the US. Managing this relationship was a major problem, both for possible direct negotiations with China and for the plan for a puppet government. At the beginning of October, the Kwantung Army bombed Jinzhou, despite the fact that it was far away from the South Manchuria Railway. This event shocked Secretary of State Stimson, who urged President Hoover to impose economic sanctions on Japan. In his view, 'the militaristic elements in Japan could learn only through suffering and not by the sanctions of public opinion, which we in America are committed to and deem enough for ourselves'. ${ }^{110}$ Hoover, however, was cautious about economic sanctions.

Of even more importance were some comments made by Secretary of State Stimson. Towards the end of November, Stimson received information that the Japanese army was being dispatched to Jinzhou. Fearful of this development, on 27 November, Stimson released to the US press corps a summary of a discussion that had taken place between Shidehara and Ambassador Forbes. ${ }^{111}$ The details of Stimson's ill-considered press conference also reached Japan. According to the evening edition of the Tokyo Asahi Shimbun (29 November), Stimson claimed that Shidehara had declared Japan would not attack Jinzhou: 
On November 24, Foreign Minister Shidehara replied that Japan had no intention of pushing further in the direction of Jinzhou. Further, in that reply, Foreign Minister Shidehara has declared that the Japanese government had already announced the above fact to the commanders of the Japanese forces in Manchuria. ${ }^{112}$

Perhaps Stimson's aim with these comments was to try to restrain Japan. Shidehara, however, responded to Stimson's thoughtlessness with a mixture of grief and anger. This was because he had told Ambassador Forbes to keep the details of their discussion confidential.

These comments were also poorly timed. As the same newspaper pointed out, the Kwantung Army central command had already ordered its forces to cancel its attack on Jinzhou. This created the impression that Japan had simply bowed to US pressure. The result was that Stimson's comments damaged the authority not only of Shidehara but also of military central command. The League of Nations had been close to bringing about an agreement on the demilitarisation of Jinzhou. Shidehara responded by having Ambassador Debuchi begin an inquiry about Stimson's press conference. ${ }^{113}$

However, the situation went in the opposite direction of Shidehara's intention. On 28 November, Stimson held a second press conference in order to defend his previous comments. An extra edition of the Tokyo Asahi Shimbun (29 November) reported that Stimson made the following statement:

On November 24, I received from Foreign Minister Shidehara, via Ambassador Forbes, the declaration that the foreign minister, the war minister, and the chief of army general staff had all reached the agreement that no military action would be taken against Jinzhou. Further, this decision had been relayed to the commander-inchief on the ground. Given this fact, I struggle to understand the newspaper reports on the mobilization of Commander-in-Chief Honjō's forces. ${ }^{114}$

This second comment by Stimson only served to make a bad situation worse. This was because he had made public some details on the supreme command of Japan's forces. These details were also more explicit than in his first statement. The source of this information, of course, was Shidehara. Naturally, Shidehara responded by issuing a protest to 
Ambassador Forbes. Upon receiving this protest, Forbes had no choice but to awkwardly apologise. Shidehara also found himself pressed by War Minister Minami during a cabinet meeting as to his own responsibility. ${ }^{115}$

Why did this situation occur in the first place? One interpretation is that the Ministry of Foreign Affairs ignored Japanese newspaper articles and instead read English-language sources such as the Associated Press. Thus they failed to grasp the essence of the problem: information relating to the supreme command had been made public by the US. For this reason, Debuchi's inquiry failed to touch upon matters such as the 'announcement' of orders to the Kwantung Army command. Therefore, when Stimson defended himself in a second press conference, he actually made matters worse by allowing further details relating to the supreme command of Japan's military to become public. This sequence of misunderstandings between Japan and the US has been pointed out by scholars and historical commentators for some time. ${ }^{116}$ Yet this explanation leaves certain basic questions unanswered. In the first place, why did Shidehara leak to Forbes details relating to the supreme command? To answer this question, we need to go back in time a little, to when Shidehara and Forbes first met.

\section{Shidehara and US Ambassador Forbes}

According to Forbes's journal, he first met Shidehara in October 1926. At that time, Forbes was visiting Japan as part of a trip around the globe. On this occasion, he met not only Shidehara but also Debuchi, Hanihara and other ministry figures. They discussed topics such as the Philippines, Korea and Taiwan. ${ }^{17}$

Later, in September 1930, Forbes would return to Japan, this time as the US ambassador. His relationship with Shidehara was a good one. One example of their relations comes from a national holiday observed at that time celebrating the Meiji emperor's birthday on 3 November. On this day, not only were celebrations held at locations such as the Imperial Palace, military facilities and schools, but also the nation's citizens raised flags above their dwellings. In Japan today, this public holiday has survived, but it has been renamed 'Culture Day'. Shidehara and Forbes had been invited to the Imperial Palace by the Shōwa emperor, where they also met with Hamaguchi and other members of the government. On that occasion, Forbes remembered telling Shidehara that 'I had just heard from California that Senator Johnson was now friendly to a much desired modification of the immigration law'. ${ }^{118}$ Another example of their strong 
relationship was from circumstances far less auspicious: they were quick to get in contact with each other after the shooting of Prime Minister Hamaguchi on 14 November.

In June 1931, Shidehara received an interesting proposal from Forbes: a suggestion to expand commercial relations between Taiwan and the Philippines. As Forbes had previously served as governor-general to the Philippines, he was far from indifferent about such matters. Shidehara responded by communicating the proposal to Ōta Masahiro, the governor-general of Taiwan, in order to get his opinion. ${ }^{119}$ Even after the outbreak of the Manchurian Incident, Shidehara and Forbes's relationship remained strong. Shidehara met with Forbes in mid-November. When Shidehara stated that he was 'definite about the utter impossibility of Japan's immediate withdrawal of troops to the railway zone because the Chinese returning soldiers would drive out all Japanese and Korean residents of Manchuria', Forbes apparently responded that this was 'unquestionably true'. ${ }^{120}$

On 3 December, however, Forbes's opinion of Shidehara abruptly shifted. In his journal, he wrote: 'Baron Shidehara has been frank and conciliatory but it is evident that the army is hard to control'. Here Forbes was referring to the comments by Stimson, which had been published at the end of November. According to Forbes: 'Secretary Stimson gave out what seemed like a perfectly fair statement outlining perhaps in a little too much detail what Japan had represented to us of her plans'. Forbes noted that when he later met Shidehara to discuss the matter, he 'was almost tearing his hair over it'. It should be noted that Forbes was not indifferent to Shidehara's situation and felt he was partially responsible. In his diary, he remarks that he had 'failed to caution Washington about the delicacy of some of the situations' but also that he 'lost no sleep over it'. He added that 'Shidehara had given me this note with the statement that it was absolutely between ourselves'. ${ }^{121}$ Following advice from counsellor Neville, Forbes decided to send a telegram to Stimson relaying Shidehara's wishes. Apparently, this message did not have a decisive impact on Stimson's thinking.

In fact, it was only after Shidehara pointed out Stimson's comments in a meeting that Forbes became aware of them. Upon returning to the embassy, Forbes confirmed the contents of the comments. Only minutes later, an Associated Press reporter burst into the room to speak with a dumbfounded Forbes. The reporter handed Forbes a copy of a statement by the Japanese Ministry of Foreign Affairs. In Forbes's 
words, the statement was 'a very bitter and intemperately worded attack on Secretary Stimson'. He noted that 'it didn't sound like Shidehara at all'. And indeed, its originator was in fact Shiratori Toshio, director-general of the Intelligence Department. Forbes relayed the details of their talks. Forbes then took the added step of apologising to Shidehara for Stimson's comments. This was when he learned that Shidehara had not written any statements of the kind that Shiratori had authored. Nevertheless, Shidehara expressed his concern that Stimson's comments 'might upset the plan of an accord between Japan and China then under negotiation'. As Forbes himself admitted, Stimson's comments 'did the opposite to Shidehara's plans'. ${ }^{122}$

As a result of this incident, criticism of Shidehara increased from the military and the Japanese public. Home Minister Adachi Kenzō, who had been pushing for a collaborative cabinet that incorporated members of the Seiyūkai party, chimed in: 'What Stimson said-that is going to become a serious political problem'. ${ }^{123}$ Adachi was entirely correct. The political fallout from this incident gave the Wakatsuki cabinet no choice but to resign. On 11 December, Shidehara was once more pushed into opposition. According to rumours that reached Forbes sometime later, Shidehara's life had also been in danger on numerous occasions. As it happened, Shidehara would not have another opportunity to meet with Forbes before he left his posting as ambassador in March 1932. ${ }^{124}$

In November of the same year, Shidehara wrote to Forbes, who had by then returned to the US. In this letter, Shidehara objected to China's actions following the Manchurian Incident. In order 'to institute direct negotiations between the two Governments on the subject, the difficulties should have been adjusted long ago', he wrote. Yet China 'failed to appreciate the singleness of purpose shown in our overtures, and sought to fight out the case at Geneva'. Shidehara concluded by observing that 'the Sino-Japanese dispute should not be allowed to drift in such a way as to affect the friendly relations between America and Japan'. ${ }^{125}$ To these comments Forbes responded sympathetically.

To summarise the above discussion, Stimson's comments must be understood in a broader context: Forbes failed to adequately warn Stimson that the details concerning Japanese supreme command had been given to him in the utmost confidence. There are also legitimate doubts as to whether either Forbes or Stimson had a correct understanding of the problem of supreme command, or of its seriousness for the 
Japanese leadership. ${ }^{126}$ Indeed, at the beginning, even Shidehara and Debuchi did not adequately grasp the essence of this problem and its political implications.

That said, an indirect cause of Stimson's comments was that Shidehara had placed too much trust in Forbes. Thus, he gave away too much information about matters relating to supreme command. These were details that normally would never have been revealed to outsiders. Shidehara had a friendly relationship with Forbes, and, as we have already seen, the building of relationships of trust was a fundamental tenet of Shidehara's 'honest diplomacy', which, in turn, constituted his guiding creed as a diplomat. On this occasion, however, Shidehara's 'honest diplomacy' led to unintended results. So, it came to pass that Shidehara ran into difficulties with the Japanese-American relationship, supposedly his field of expertise, and left the ministry to which he was so attached. Along the way, over 35 years had passed since he began as a consular assistant. It was early winter, and not long before his sixtieth birthday.

\section{Endnotes}

1 Itō and Hirose, Makino Nobuaki Nikki, 379; Ministry of Foreign Affairs Hundred-Year History Compilation Association, Gaimushō no 100 Nen, vol. 1, 928.

2 Kawashima Nobutarō to Ujita Naoyoshi, 1 July 1953, in 'Shidehara Heiwa Bunko', Reel 18.

3 'Eikoku Taishikan Sanjikan Saburi Sadao-kun no Enzetsu [A Speech by Mr. Saburi Sadao, Counsellor, Japanese Embassy in the U.K.], in Osaka Economic Association, ed., Ōsaka Keizaikai Joshükai niokeru Enzetsu [A Speech Given at the Regular Convention of the Osaka Economic Association] (Osaka: Osaka Economic Association, 1929), 2-5.

4 Shidehara, Gaikō 50 Nen, 102-103.

5 Tokyo Asahi Shimbun, 30 November, 1 December and 2 December 1929.

6 Shigemitsu Mamoru, 'Saburi Kōshi no Shi' [The death of Minister Saburi], Chügoku Kenkyū Geppō 42, no. 11 (November 1988): 38-42.

7 Horinouchi, Horinouchi Kensuke Kaikoroku, 55-57.

8 Hattori, Higashi Asia Kokusai Kankyō no Hendō to Nihon Gaikō, 1918-1931, 264-65.

9 Shidehara, 'Washington Kaigi no Rimen-kan Sonota', 127-31; Hattori, Higashi Asia Kokusai Kankyō no Hendō to Nihon Gaikō, 1918-1931, 255-63.

10 See Akami Tomoko, Internationalizing the Pacific: The United States, Japan and the Institute of Pacific Relations in War and Peace, 1919-1945 (London: Routledge, 2002).

11 Horiuchi to Shidehara, 16 September 1929, in 'Taiheiyō Mondai Chōsa-kai Kankei Ikken' [Institute of Pacific Relations], vol. 1, B.10.1.0.3, Diplomatic Archives of the Ministry of Foreign Affairs of Japan.

12 Interview with Baron Shidehara, 15 April 1926, in Ray Lyman Wilbur Papers, Box 42, Hoover Institution, Stanford University; Hattori Ryūji, 'Tanaka Jōsōbun to Nicchū Kankei' [The Tanaka memorial and the Sino-Japanese Relations], in Minkoku Köki Chügoku Kokumin-tō Seiken no Kenkyū [A study of the Chinese nationalist government in the late period of the Republic of China], ed. Chuo University Institute of Cultural Sciences (Hachiōji: Chūō University Press, 2005), 455-93; 
Hattori Ryūji, ‘Tanaka Jōsōbun wo Meguru Ronsō: Jitsuzon-setsu to Gizō-setsu no Aida' [The debate surrounding the 'Tanaka memorial to the emperor': Between theories of its authenticity and its fabrication], in Kokkyō wo Koeru Rekishi Ninshiki: Nicchü Taiwa no Kokoromi [Historical consciousness transcending national boundaries: An attempt at Sino-Japanese dialogue], ed. Liu Jie, Hiroshi Mitani, and Yang Daqing (University of Tokyo Press, 2006), 84-110.

13 Shidehara to Neville, US representative ambassador to Japan, 14 October 1929, in 'Bei Doku Chūsai Saiban narabini Wakai Jōyaku Kankei Ikken (Chōtei Jōyaku Shotei no Jōsetsu Iinkai wo Fukumu)' [Documents relating to the treaty on arbitration and amicable settlement between the US and Germany (including the permanent commission under the conciliation treaty)], B.5.0.0.G/ U1, Diplomatic Archives of the Ministry of Foreign Affairs of Japan; Shidehara to Ernest Arthur Voreizsch, German ambassador to Japan, 14 October, ibid.; Shidehara, Gaikö 50 Nen, 157-58.

14 This section is based on my previous work: Hattori Ryūji, 'London Kaigun Gunshuku Kaigi to Nichi-Bei Kankei: Castle Chu-Nichi Beikoku Taishi no Manazashi' [The London Naval Conference on Disarmament and Japan-US relations: The gaze of Castle, US ambassador to Japan], Shigaku Zasshi 112, no. 7 (July 2003): 59-84.

15 For details on Japan's movements with respect to the London Conference, see Kobayashi Tatsuo, 'Kaigun Gunshuku Jōyaku' [The naval disarmament treaty], in Taiheiyō Sensō eno Michi: Kaisen Gaikō-shi [The road to the Pacific War: A diplomatic history of the commencement of the war], ed. Japanese International Politics Society Research Division for Causes of the Pacific War, vol. 1 (Tokyo: Asahi Shimbunsha, 1963), 1-160; Ikeda Kiyoshi, 'London Kaigun Jōyaku to Tōsuiken Mondai' [The London Naval Treaty and the problem of supreme command], Ōsaka Shiritsu Daigaku Hōgaku Zasshi 15, no. 2 (October 1968): 1-35; Itō Takashi, Shōwa Shoki Seijishi Kenkyū: London Kaigun Gunshuku Mondai wo Meguru Sho-Seiji Shüdan no Taikō to Teikei [A study of the political history of the early Shōwa period: Confrontation and partnership between various political organizations with respect to the London naval disarmament problem] (Tokyo: University of Tokyo Press, 1969); Shibata Shinichi, 'London Kaigun Gunshuku Kaigi nikansuru Ichi-Gokuhi-Den: Na wo Tsuraneta Hitobito to Yoshida Shigeru no Sono Go' [A top-secret telegram relating to the London Naval Conference on Disarmament: Participating individuals and what happened to Yoshida Shigeru afterwards], in., Ningen, Yoshida Shigeru [The person, Yoshida Shigeru], ed. Yoshida Shigeru Memorial Project Foundation (Tokyo: Chuōkōronsha, 1991), 249-66; Ikei Masaru and Hatano Masaru, 'London Kaigun Gunshuku Mondai to Hamaguchi Osachi' [The London naval disarmament problem and Hamaguchi Osachi], Högaku Kenkyū 63, no. 11 (November 1990): 1-34; Masuda Tomoko, Tennōsei to Kokka: Kindai Nihon no Rikken Kunshusei [The emperor system and the nation-state: Modern Japan's constitutional monarchy] (Tokyo: Aoki Shoten, 1999), 149-79; Kurono Taeru, Teikoku Kokubō Hōshin no Kenkyū: Riku-Kai-Gun Kokubō Shisō no Tenkai to Tokuchō [A study of the imperial defence policy: The development and characteristics of national defence theory in the army and navy] (Tokyo: Sōwasha, 2000), 275-95; Ōmae Shinya, 'London Kaigun Gunshuku Mondai niokeru Zaisei to Gunbi: Kaigun Hojū Mondai wo Meguru Seiji Katei' [The finance and armaments in the London naval disarmament problem: The political process surrounding the naval replenishment problem], Suzuka Kokusai Daigaku Kiyō, no. 7 (March 2000): 13-57; Banno Junji, Nihon Seiji 'Shippai' no Kenkyü: Chüto Hanpa Gonomi no Kokumin no Yukue [Research on the 'failure' of Japanese politics: Which way for a citizenry that favours half-measures] (Tokyo: Kōbōsha, 2001), 75-103; Katō Yōko, Sensō no Ronri: Nichi-Ro Sensō kara Taiheiyō Sensō Made [The logic of war: From the Russo-Japanese war to the Pacific War] (Tokyo: Keisō Shobō, 2005), 106-41; Itō Yukio, Shōwa Tennō to Rikken Kunshusei no Hökai [The Shōwa emperor and the collapse of the system of constitutional monarchy] (Nagoya: Nagoya University Press, 2005), 139-224.

For previous research that assesses this topic from the perspective of Japanese-American relations, see Charles E. Neu, translated by Banno Junji, 'Higashi Asia niokeru America Gaikōkan' [American diplomats in East Asia], in Washington Taisei to Nichi-Bei Kankei [The Washington system and JapanUS relations], ed. Hosoya Chihiro and Saitō Makoto (Tokyo: University of Tokyo Press, 1978), 21457; Kitaoka Shinichi, 'Washington Taisei to "Kokusai Kyōchō" no Seishin: MacMurray Memorandum (1935 Nen) niyosete' [The Washington system and the spirit of 'international cooperation': Examining the MacMurray memorandum (1935)], Rikkyō Högaku, no. 23 (December 1984): 68-113; Mitani Taiichirō, 'Senzen, Senchū-ki Nichi-Bei Kankei niokeru Beikoku Shinnichi-ha Gaikōkan no Yakuwari' [The role of US pro-Japan faction diplomats with respect to the Japan-US relationship during the 
prewar and wartime periods] (1) (2) (3) (4), Gaikō Forum 4, no. 9 (September 1991): 83-92, no. 10 (October 1991): 81-92, no. 11 (November 1991): 81-92, (December 1991): 67-80; Asada, RyōTaisen-kan no Nichi-Bei Kankei, 176-91; Hu, Stanley K. Hornbeck and the Open Door Policy, 19191937, 113-20; Alfred L. Castle, 'Ambassador Castle's Role in the Negotiations of the London Naval Conference' Naval History, (summer 1989): 16-21; Alfred L. Castle, Diplomatic Realism: William R. Castle, Jr., and American Foreign Policy, 1919-1953 (Honolulu: University of Hawaii Press, 1998), 37-49; Iguchi Haruo, 'America no Kyokutō Seisaku: Herbert C. Hoover to Nichi-Bei Kankei' [The US's Far East policy: Herbert C. Hoover and Japan-US relations], in Kan-Taiheiyō no Kokusai Chitsujo no Mosaku to Nihon: Daiichiji Sekai Taisen-go kara 55 Nen Taisei Seiritsu [The search for an international order in the greater Pacific and Japan: From the aftermath of World War I to the establishment of the 1955 system], ed. Itō Yukio and Kawada Minoru (Tokyo: Yamakawa Shuppansha, 1999), 5-43.

16 Castle, who served as the US ambassador to Japan, recorded some of his own observations of the early stages of the London conference. See Castle to Cotton, 25 January 1930, Department of State, ed., FRUS, 1930, vol. 1 (Washington: Government Printing Office, 1945), 9-10.

17 His diary is held in Harvard University's Houghton Library. See William R. Castle, Jr., diary, Houghton Library, Harvard University; other Castle documents are found in the Herbert Hoover Presidential Library. See William R. Castle, Jr, Papers, Herbert Hoover Presidential Library.

18 Castle diary, vol. 16, 5 January 1930.

19 Castle diary, vol. 15, 11 December 1929.

20 Hattori, Higashi Asia Kokusai Kankyō no Hendō to Nihon Gaikō, 1918-1931, 255-63.

21 Ministry of Foreign Affairs, ed., Nihon Gaikō Bunsho: 1930 Nen London Kaigun Kaigi [Documents on Japanese foreign policy: The 1930 London Naval Conference], vol. 1 (Tokyo: Ministry of Foreign Affairs, 1983), 304-10.

22 Japanese delegation to Shidehara, 10 January 1930, ibid., 403-08.

23 Castle diary, vol. 16, 20 January 1930.

24 Castle diary, vol. 16, 24 January 1930.

25 Castle to Hoover, 27 January 1930, Herbert Hoover Papers, Box 995, Herbert Hoover Presidential Library.

26 Ibid.

27 Castle to Cotton, 14 February 1930, in Department of State, FRUS, 1930, vol. 1, 24-25.

28 Castle's diary, vol. 16, 15 February 1930. See also Shidehara to Japanese delegation, 15 February 1930, in Ministry of Foreign Affairs, ed., Nihon Gaikö Bunsho: 1930 Nen London Kaigun Kaigi, vol. 2 (Tokyo: Ministry of Foreign Affairs, 1984), 79-83.

29 Hirata Shinsaku, 'Beikoku Taishi Sai-Kaiken-ki' [Records of another meeting with the US ambassador], Nihon oyobi Nihonjin, no. 199 (March 1930): 73-76. The same manuscript was distributed in the form of a pamphlet. It is included in texts such as 'London Kaigun Kaigi Ikken: Yoron narabini Shimbun Ronchō (Honpō)' [London navy meeting: Public opinion and press comments (Japan)], vol. 2., B.12.0.0.1-4, Diplomatic Archives of the Ministry of Foreign Affairs of Japan; 'Saitō Makoto Kankei Bunsho' [Documents relating to Saitō Makoto], Document Department, Reel 249, Modern Japanese Political History Materials Room, National Diet Library.

For a monograph that outlines Hirata's thinking on disarmament, see Hirata Shinsaku, Gunshuku no Fuan to Taiheiyō Sensō [Concerns about disarmament and a Pacific War] (Tokyo: Tenjinsha, 1930). Pages 106-07, 125, and 213 contain criticism of Shidehara. On page 129 of the same text, Hirata stated that, when he subsequently met with Castle, Castle did his utmost to conceal that the US viewed Japan as a potential enemy. However, in Castle's own diary, there is no entry corresponding to Hirata's description of such a discussion.

For research on Hirata Shinsaku, see Sawada Jirō, Kindai Nihonjin no America-kan: Nichi-Ro Sensō Igo wo Chüshin ni [The modern Japanese perspective on the US: Focusing on the period following the Russo-Japanese War] (Tokyo: Keiō University Press, 1999), iv, 221-82; Louise Young, Sōdōin Teikoku [Japan's Total Empire], trans. Katō Yōko, Kawashima Shin, Takamitsu Yoshie, Chiba Isao and Furuichi Daisuke (Tokyo: Iwanami Shoten, 2001), 46. 
30 Castle to Cotton, 24 February 1930, in Department of State, FRUS, 1930, vol. 1, 30; Shidehara-Castle talks, 25 February 1930, in Ministry of Foreign Affairs, Nihon Gaikö Bunsho: 1930 Nen London Kaigun Kaigi, vol. 2, 95-97; Castle diary, vol. 16, 26 February 1930.

31 Japanese delegation to Shidehara, 26 February 1930, in Ministry of Foreign Affairs, Nihon Gaikō Bunsho: 1930 Nen London Kaigun Kaigi, vol. 2, 97-99.

32 Castle to Cotton, 7 March 1930, in Department of State, FRUS, 1930, vol. 1, 49-51; Castle diary, vol. 16, 9 March 1930.

33 Ministry of Foreign Affairs, Nihon Gaikō Nenpyō narabini Shuyō Bunsho, vol. 1, 143-44; Shidehara to Japanese delegation, 15 March 1930, in Ministry of Foreign Affairs, Nihon Gaikö Nenpyō narabini Shuyō Bunsho, vol. 2, 133-34.

34 Ikei, Hatano and Kurosawa, Hamaguchi Osachi Nikki, Zuikanroku, 312-443; Yoshida to Makino, 26 January 1930, in Yoshida Shigeru Memorial Project Foundation, Yoshida Shigeru Shokan, 62728; diary of Katō Hiroharu, 21-25 January 1930, in Zoku Gendai-shi Shiryō, vol. 5: Kaigun-Katō Hiroharu Nikki [Modern historical material, continued, 5: The navy-the diary of Katō Hiroharu], ed. Itō Takashi, Suzuki Jun, Koike Seiichi, Taura Masanori and Furukawa Takahisa (Tokyo: Misuzu Shobō, 1994), 90; diary of Okada Keisuke, 23 March - 2 April 1930, in Okada Keisuke Kaikoroku [The memoirs of Okada Keisuke], ed. Okada Sadahiro (Tokyo: Chūōkōronsha, 1987), 265-75.

35 Harada Kumao, Saionji-kō to Seikyoku [Lord Saionji and the political situation], vol. 1 (Tokyo: Iwanami Shoten, 1950), 28, 32-36; Suzuki Hajime, ed., Suzuki Kantarō Jiden [The autobiography of Suzuki Kantarō] (Tokyo: Jiji Tsūshinsha), 1968, 255-58; Takahashi Hiroshi, Awaya Kentarō and Otabe Yūji, eds, Shōwa Shoki no Tennō to Kyūchū: Jijüjichō Kawai Yahachi Nikki [The emperor and the imperial court in the early Shōwa period: The diary of Deputy Grand Chamberlain Kawai Yahachi], vol. 4 (Tokyo: Iwanami Shoten, 1994), 48-50, 56, 89; Shōyū Society Incorporated, Okabe Nagakage Nikki, 330; Castle diary, vol. 16, 16 March 1930. While the Makino Nobuaki diary entries for February to July 1930 are missing, there are still entries, such as that for 13 September, that reveal his support for the Hamaguchi cabinet. See Itō and Hirose, Makino Nobuaki Nikki, 408.

36 Castle to Cotton, 18 March 1930, in Department of State, FRUS, 1930, vol. 1, 66-67.

In his entry for 27 March 1930, Naval General Staff Director Katō wrote: 'Meeting with Prime Minister Hamaguchi at 3 o'clock this afternoon at the prime minister's residence. General Okada was also in attendance and stressed his objections'. See Itō et al., Zoku Gendai-shi Shiryō, vol. 5, 93. See also the discussion with Tōgō Heihachirō, on 16 March 1930, ibid., 469-70.

37 Ikei, Hatano and Kurosawa, Hamaguchi Osachi Nikki, Zuikanroku, 313-443; Shidehara to Japanese delegation, 18 March 1930, in Ministry of Foreign Affairs, Nihon Gaikō Bunsho: 1930 Nen London Kaigun Kaigi, vol. 2, 141-42.

According to Harada, Saionji-kō to Seikyoku, vol. 1, 25:

Meanwhile, a statement of some form was suddenly issued from the Naval General Staff. The vice-chief handed it over to the Rengō Tsushin company. Basically, of the so-called three basic principles of the navy, the two principles of maintaining 70 per cent cruisers and 78,000 tons of submersibles would be adhered to, no matter what.

A related statement can be found in the Hamaguchi Osachi diary from 22 March 1930:

We received a phone call from the foreign minister regarding a libelous document issued by the navy (this was now the second such inflammatory document, but it did not make it into the newspapers).

See Ikei, Hatano and Kurosawa, Hamaguchi Osachi Nikki, Zuikanroku, 315. A similar statement appears in ibid., 443-44.

According to a journal entry of the same date by Adjutant General Hori:

Vice-Chief Suetsugu knew that newspaper reporters were aware of the distribution of 'prints' concerning the present problem and took action to prevent their disclosure. However, several smaller papers nevertheless proceeded to publish them. 
See Kobayashi Tatsuo and Shimada Toshihiko, eds, Gendai-shi Shiryo, vol. 7: Manshü Jihen [Modern historical material, vol. 7: The Manchurian Incident] (Tokyo: Misuzu Shobō, 1964), 36. Tokyo Nichi Shimbun is the Mainichi Shimbun at present.

38 Ministry of Foreign Affairs Research Department, Section 4, ed., 'Wakatsuki Reijirō Dan Jutsu London Kaigun Gunshuku Kaigi [The London Naval Conference on Disarmament, described by Baron Wakatsuki Reijirō], 10 October 1939, in Hirose, Kindai Gaikō Kaikoroku, vol. 3, 248; Shidehara to Japanese delegation, 19 March 1930, in Ministry of Foreign Affairs, Nihon Gaiko Bunsho: 1930 Nen London Kaigun Kaigi, vol. 2, 144-46; Castle diary, vol. 16, 18 March 1930; Shidehara to Japanese delegation, 19 March 1930, in Ministry of Foreign Affairs, Nihon Gaiko Bunsho: 1930 Nen London Kaigun Kaigi, vol. 2, 147-49. Wakatsuki also stated that there were those among the delegation who argued in favour of cooperation between Japan and France, yet he did not specify who those individuals were. See Wakatsuki Reijirō, Meiji, Taishō, Shōwa Seikai Hishi: Kofü-an Kaikoroku [A secret history of the political world of the Meiji, Taishō and Shōwa eras: Memoirs of an old-fashioned man] (Tokyo: Kōdansha, 1983), 311.

39 Shidehara to Saitō Makoto, 21 March 1930, in 'Saitō Makoto Kankei Bunsho', Document Department, Reel 34; Henry Lewis Stimson diary, 19 March 1930, Henry Lewis Stimson Papers, Reel 2, Yale University Library.

40 Castle diary, vol. 16, 21 March 1930.

41 Castle candidly presented this opinion to President Hoover in correspondence, writing:

I have not seen and do not expect to see the Prime Minister. He is a silent man who speaks only Japanese and is not known by any of the Diplomatic Corps. If I asked for an interview it would probably be given but it would create a sensation in the press which would have a very bad effect.

Conversely, Castle spoke highly of Finance Minister Inoue and Foreign Minister Shidehara. Another important point in Castle's correspondence with Hoover was his noting that he was using Makino, the lord keeper of the Privy Seal, as a mediator for communicating with the Shōwa emperor. To put it simply, the scenario presented by Castle was that Shidehara would summarise the cabinet's diplomatic instructions and Makino would convince the emperor. In any respect, Castle's position was that 'I must work within the recognized channels'. See Castle to Hoover, 25 March 1930, Hoover Papers, Box 995. See also Castle to Cotton, 21 March 1930, in Department of State, FRUS, 1930, vol. 1, 70.

42 Castle's diary, vol. 16, 24 March 1930; Stimson to Cotton, 2 March 1930, in Department of State, FRUS, 1930, vol. 1, 75; Stimson to Cotton, 28 March, ibid., 91; Shidehara to Japanese delegation, 19 March 1930, in Ministry of Foreign Affairs, Nihon Gaikö Bunsho: 1930 Nen London Kaigun Kaigi, vol. 2, 149-51; Shidehara to Japanese delegation, March 24, ibid., 165-66.

43 Shidehara to Japanese delegation, 24 March 1930, in Ministry of Foreign Affairs, Nihon Gaikō Bunsho: 1930 Nen London Kaigun Kaigi, vol. 2, 164-65; Shidehara to Japanese delegation, 24 March 1930, ibid., 165-66. After Castle returned home, he checked with Ballantine concerning the circumstances of the message sent to Hamaguchi. See Ballantine memoirs, Joseph W. Ballantine Papers, Box 1, Hoover Institution, Stanford University.

44 Ministry of Foreign Affairs, Nihon Gaikō Nenpyō narabini Shuyō Bunsho, vol. 2, 147-57; Ikei, Hatano and Kurosawa, Hamaguchi Osachi Nikki, Zuikanroku, 320, 445-47; Kawada Minoru, ed., Hamaguchi Osachi Shü: Ronjütsu, Koen Hen [The Hamaguchi Osachi collection: Statements, lectures section] (Tokyo: Miraisha, 2000), 253-56; Castle's diary, vol. 16, 3 April 1930; from Stimson to Cotton, 1 April 1930, in Department of State, FRUS, 1930, vol. 1, 99-100.

45 Diary of Nara Takeji, 1 April 1930, in Jijü Bukanchō Nara Takeji Nikki, Kaikoroku [The diary and memoirs of Nara Takeji, chief aide-de-camp to the emperor of Japan], ed. Hatano Sumio, Kurosawa Fumitaka, Hatano Masaru, Sakurai Ryōju and Kobayashi Kazuyuki, vol. 3 (Tokyo: Kashiwa Shobō, 2000), 217.

46 Inaba Masao, Kobayashi Tatsuo, Shimada Toshihiko and Tsunoda Jun, eds, Taiheiyō Sensō eno Michi: Kaisen Gaikō-shi [The road to the Pacific War: A diplomatic history of the commencement of the war], extra vol.: Resources (Tokyo: Asahi Shimbunsha, 1963), 48. See also Itō et al., Zoku Gendaishi Shiryō, vol. 5, 94. 
47 Diary of Nara Takeji, 2 April 1930, in Hatano et al., Jijü Bukanchō Nara Takeji Nikki, Kaikoroku, vol. 3, 217.

48 In fact, as indicated by the aforementioned Kato Jōsōbun (report to the throne), the point of emphasis was: 'it will bring about a serious change in our plan of operations based upon the policy of national defense'.

The report 'London Kaigun Jōyaku Teiketsu Keii' [The circumstances of the signing of the London Naval Reduction Treaty], arranged at the end of 1930 by Adjutant General Hori Teikichi, having also quoted this section, states:

The public have even mistakenly viewed this report to the throne as constituting an objection to the diplomatic instructions issued by the government ... whereas it in fact corresponded with the unanimous agreement reached by the House of Councilors' meeting on military affairs, held at a later date.

See Inaba et al., Taiheiyō Sensō eno Michi, extra vol.: Resources, 48; Kobayashi and Shimada, Gendaishi Shiryo, vol. 7, 92; 'Hōtōbun' [Reply to the throne] is included in Inaba et al., Taiheiyō Sensō eno Michi, extra vol.: Resources, 55-56; Kobayashi and Shimada, Gendai-shi Shiryo, vol. 7, 96.

Further, just after the report to the throne, Katō made the following statement to the press:

While I cannot agree to the number of troops proposed by the United States ... with respect to the current instructions, the navy will be sure to not act rashly, adjusting to the circumstances as they unfold and taking the appropriate steps.

See Tokyo Asahi Shimbun, evening edition, April 3, 1930.

49 Consequently, at the House of Peers society meeting (5 April), Suetsugu presented figures for the Japan-US compromise proposal, asserting: 'light cruisers are at 70\%, however, large cruisers are at $60 \%$, in line with the initial U.S. request, and submersibles are to be reduced to one-third of the current number'. He added: 'As [vice-chief of] the Naval General Staff, I presented my own position to the emperor in a report the following day [2 April]'. Suetsugu further argued: 'If Japan simply gives in to the proposal of the U.S., we will be unable to have a single large cruiser or a single submersible', and he concluded with the assertion that, 'the establishment of such an agreement would naturally lead to critical shortcomings in national defense'. See Hatano Masaru, 'Hamaguchi-ke Shozō no "Hamaguchi Osachi Bunsho"' ['Hamaguchi Osachi documents' held by the Hamaguchi family], Högaku Kenkyü 67, no. 7 (July 1994): 103-05.

50 Meeting between the Shōwa emperor and John Tilley, ambassador for the UK, 13 April 1930, in 'London Kaigun Kaigi Ikken' [London Navy Meeting], vol. 2, B.12.0.0.1-4, Diplomatic Archives of the Ministry of Foreign Affairs of Japan.

51 Shidehara to Japanese delegation, 15 April, in 'London Kaigun Kaigi Ikken', vol. 2; Sawada, Gaisenmon Hiroba, 114-16; Shibata, 'London Kaigun Gunshuku Kaigi nikansuru Ichi-GokuhiDen', 249-66; Hatano, Hirohito Kötaishi Europe Gaiyü-ki, 206.

52 Department of State, FRUS, 1930, vol. 1, 107-25; Ministry of Foreign Affairs, Nihon Gaikō Nenpyō narabini Shuyō Bunsho, vol. 2, 159-61.

53 Teikoku Gikai Shügiin Giji Sokkiroku [Shorthand record of the proceedings of the Imperial Diet House of Representatives], vol. 54 (Tokyo: University of Tokyo Press, 1983), 13, 16, 26.

54 Itō et al., Zoku Gendai-shi Shiryō, vol. 5, 96; diary of Okada Keisuke, 2 and 11 May 1930, in Okada, Okada Keisuke Kaikoroku, 281-82, 286-87. Katōs displeasure with Shidehara is outlined in Harada, Saionji-kō to Seikyoku, vol. 1, 47. Katō's views on the violation of supreme command authority (tösuiken kanpan) are evident in his correspondence to Saitō Makoto, 6 May 1930, in 'Saitō Makoto Kankei Bunsho', Document Department, Reel 164.

55 The Seiyūkai asserted, quite bombastically, that Grand Chamberlain Suzuki Kantarō had colluded with the cabinet to prevent the 'Kato Jös $\vec{o}$ (Katồ's report to the throne) before the diplomatic instructions were sent. Reflecting on this period, Suzuki Kantarō wrote: 
At the time, I felt annoyed that the chief of the Naval General Staff did not have a suitably clear understanding of the responsibilities of his own position, and that this led to a lot of pointless confusion. Reflecting upon that problem now from a broader perspective, I think that one way of interpreting the situation was that the chief of the Naval General Staff was played with by some conspirators within the Seiyūkai.

See Harada, Saionji-kō to Seikyoku, vol. 1, 48; Suzuki, Suzuki Kantarō Jiden, 258. It should also be noted that in 'London Gunshuku Kaigi-ron' [My view on the London Naval Conference on Disarmament], November 1933, Kobayashi Seizō argued that the opposition party was in 'collusion' with the Naval General Staff. See Itō Takashi and Nomura Minoru, eds, Kaigun Taishō Kobayashi Seizō Oboegaki [The memorandum of Admiral Kobayashi Seizō] (Tokyo: Yamakawa Shuppansha, 1981), 60 .

56 Castle diary, vol. 16, 8 May 1930.

57 Castle diary, vol. 16, 31 May 1930.

58 Castle to Stimson, 26 April 1930, Nelson T. Johnson Papers, vol. 13, Manuscript Division, Library of Congress.

59 'Teikoku no Tai-Shi Gaikō Seisaku Kankei Ikken' [Diplomatic policy of Japan towards China], vol. 2, A.1.1.0.10, Diplomatic Archives of the Ministry of Foreign Affairs of Japan. See also Koike, Manshū Jihen to Tai-Chūgoku Seisaku, 32; Nishida Toshihiro, 'Washington Taisei no Henyō to Shidehara Gaikō: 1929-1931 Nen' [Shifts in the Washington system and Shidehara diplomacy: 1929-1931] (1), Hōgaku Ronsō 149, no. 3 (June 2001): 89.

60 Teikoku no Tai-Shi Gaikō Seisaku Kankei Ikken', vol. 2.

61 Castle diary, vol. 16, 23, 28, 29, 31 May 1930.

62 Address by Castle at dinner hosted by the America-Japan Society at the Peers' Club, 23 May 1930, Castle Papers, Box 27. See also address by Tokugawa, 23 May 1930, in 'Nichi-Bei Kyōkai Shiryō' [Historical documents of the America-Japan Society], A5-05, America-Japan Society; Tokyo Asahi Shimbun, 24 May 1930; Trans-Pacific, 29 May 1930, in Castle Papers, Box 27; Hirobe, Japanese Pride, American Prejudice, 135.

63 Address by Hanihara, 23 May 1930, America-Japan Society Special Bulletin, no. 11 (1931): 14-16, in 'Nichi-Bei Kyōkai Shiryō', C3-11.

64 John Tilley, London to Tokyo (London: Hutchinson, 1942), 204.

65 Sawada Setsuzō, consul general in New York, to Shidehara, 13 February 1930, in 'Makino Nobuaki Kankei Bunsho', Document Department, Reel 35; Debuchi Katsuji, ambassador to the US, to Shidehara, 26 February, ibid.

66 Castle remained the ambassador to Japan from the evening after returning home until the end of June. On 30 June, Castle wrote a letter to Matsudaira, Japan's ambassador to the UK, expressing some regret that his service as ambassador was due to end just a few hours later. In this letter, Castle praised the results of the Matsudaira-Reed negotiations and then remarked on how to approach the disarmament treaty:

It is true that the best treaty is one which will be gladly accepted by all parties concerned, but I doubt whether this is ever possible in a treaty which has broad political angles. The next best treaty, therefore, is one which causes irritation in all the countries concerned because then one can well believe that all have made wise compromises for the sake of a happy result.

Castle to Matsudaira, 30 June 1930, Castle Papers, Box 9.

67 Castle to Shidehara, 25 June 1930, Castle Papers, Box 9; Shidehara to Castle, 27 July 1930, Castle Papers, Box 9.

68 Castle to Forbes, 27 June 1930, Castle Papers, Box 9; Kimura Atsushi, consul in Chicago, to Shidehara, 12 July 1930, in 'London Kaigun Kaigi Ikken: Yoron narabini Shimbun Ronchō (Beikoku)' [London navy meeting: Public opinion and press comments (the U.S.)], B.12.0.0.1-4, Diplomatic Archives of the Ministry of Foreign Affairs of Japan; Chugai Shögyo Shinpo, 29 August 
1930. Forbes was also residing in the Imperial Hotel, which was not exactly a pleasant place to stay. See Forbes to Castle, 18 September 1930, Castle Papers, Box 9. The completion of the US ambassador's residence would have to wait until 1931.

69 Reminiscences of Sansom; Inoue Junnosuke Essay Collection Editing Association, ed., Inoue Junnosuke: Ronsō [Inoue Junnosuke: Essay Collection], vol. 4 (Tokyo: Hara Shobō, 1982), 557-60.

70 Castle to Shidehara, 3 October 1930, Castle Papers, Box 9. Drafts of letters from Shidehara to Castle in September 1930 that outline the attitudes of the Privy Council can be found in 'Makino Nobuaki Kankei Bunsho', Document Department, Reel 18.

Katō's successor was Admiral Taniguchi Naomi. According to the Bureau of Naval Affairs Chief Hori Teikichi (in the aforementioned 'London Kaigun Jōyaku Teiketsu Keii'):

Even though the change of naval general staff director happened on that very day, the minister had arranged it. This was done, of course, not because Chief of the Naval General Staff Katō's report to the throne was delivered.

See also Kobayashi and Shimada, Gendai-shi Shiryo, vol. 7, 94.

Further, in his diary entry for 10 June, Nara Takeji stated that the emperor also went through Nara to secure Tōgō Heihachirō's approval to have Taniguchi installed in this position. At the time, Tōgō responded:

To the effect that he felt it extremely regrettable that the treaty details were improper, and that diplomatic instructions have been issued without first receiving the approval of the Naval General Staff.

Tōgō also 'expressed dissatisfaction with the actions of plenipotentiary Takarabe'. See Hatano et al., Jijü Bukanchō Nara Takeji Nikki, Kaikoroku, vol. 3, 235-36. Banno, Nihon Seiji 'Shippai' no Kenkyzu, 93, looks at the diary entry from that same day in Takarabe Takeshi's diary, asserting that the emperor did not respond directly to Katō's resignation; instead, he entrusted Navy Minister Takarabe to consider the matter. Takarabe issued a report to the effect that Taniguchi supported the London Treaty. It was only after receiving this confirmation that the emperor gave his own approval. See 'Takarabe Takeshi Kankei Bunsho' [Documents relating to Takarabe Takeshi], vol. 41, Modern Japanese Political History Materials Room, National Diet Library.

On that same day, 10 June, both Navy Vice-Minister Yamanashi and Suetsugu, vice chief of the Naval General Staff, were transferred from their roles. According to the Bureau of Naval Affairs Chief Hori Teikichi, in 'London Kaigun Jōyaku Teiketsu Keii', the former was transferred due to illness, while the latter was transferred due to voicing his personal views in a newspaper on 17 March. See Kobayashi and Shimada, Gendai-shi Shiryo, vol. 7, 95. Their replacements were Vice Admiral Kobayashi Seizō and Vice Admiral Nagano Osami, respectively.

71 Debuchi Katsuji, 'Beikoku Hai-Nichi Imin-hō Shūsei Mondai' [The US Japanese Exclusion Act revision problem], October 1939, in Hirose, Kindai Gaikō Kaikoroku, vol. 4, 225-75; memorandum by Stimson, 30 October 1930, in Department of State, FRUS, 1930, vol. 3 (Washington: Government Printing Office, 1945), 315. See also Takahashi Katsuhiro, "Beikoku Hai-Nichi Imin-hō Shūsei Mondai” to Chu-Bei Taishi Debuchi Katsuji' ['The US Japanese Exclusion Act revision problem' and Ambassador to the US Debuchi Katsuji], Nihon Rekishi, no. 523 (December 1991): 59-75.

72 In other words, according to Castle, 'Debuchi realizes that he will not remain very much longer as Ambassador in Washington and that, for the sake of his own reputation, he wants to clear up this situation'. The aforementioned correspondence with Shidehara implies that Castle thought Shidehara was prudent about the immigration problem and, conversely, he saw Debuchi's attitude as rash. According to Castle's understanding, Debuchi was also in a hurry to resolve the immigration problem, because he wanted Japan to stay within the framework of the naval treaty.

However, Castle thought that the naval issue and the immigration problem should not be directly linked. On this matter, Castle received confirmation from senators Reed and Robinson and Secretary of State Stimson and sent a private message to Forbes. These details also indicate that Castle had more trust in Shidehara than in Debuchi. See Castle to Forbes, 4 December 1930, Castle Papers, Box 9.

73 Castle to Dooman, 10 October 1930, Castle Papers, Box 9; Johnson to Hornbeck, 31 October 1930, Johnson Papers, vol. 14. 
74 As one example, on the matter of what measures to take with respect to the Sino-Soviet conflict that broke out in the fall of 1929 , G. C. Hanson, US consul in Harbin, created a lengthy memorandum together with members of the State Department's Division of Far Eastern Affairs. However, what was handed over to Stimson from Hornbeck was only the concluding section. The section stated that Stimson's approach to China led to the restoration of the Chinese Eastern Railway. The conservative of Chinese north-eastern political power was also viewed as having a close relationship with Japan. See Hornbeck to Stimson, 4 November 1930, Stimson Papers, Reel 80.

75 Teikoku Gikai Shügiin Iinkaigiroku [Record of the Imperial Diet House of Representatives Committee], Reel 6 (Tokyo: Rinsen Shoten, 1989), 196-202.

76 Ibid., 199.

77 Shidehara, Gaikō 50 Nen, 137-39; Nitobe to Castle, 7 March 1931, Castle Papers, Box 9.

78 For further details on this point, see Hattori, Higashi Asia Kokusai Kankyō no Hendō to Nihon Gaikō, 1918-1931, Chapter 1.

79 Castle to Hoover, 7 April 1930, Hoover Papers, Box 995.

80 Castle diary, vol. 16, 27 April 1930.

81 Imperial Japanese Naval General Staff, 'Washington Kaigi-go niokeru Beikoku no Senbi' [US military preparedness following the Washington Conference], 14 December 1929, in 'Saitō Makoto Kankei Bunsho', Document Department, Reel 164; Katō Hiroharu, 'Gunshuku Shoken' [Opinion on disarmament], January 1930, ibid.; Seventh London Naval Treaty Investigation Committee, 5 September 1930, in Nihon Gaikō Bunsho: Kaigun Gunbi Seigen Jōyaku Sümitsuin Shinsa Kiroku [Documents on Japanese foreign policy: Naval Armament Limitation Treaty Privy Council investigation records], ed. Ministry of Foreign Affairs (Tokyo: Ministry of Foreign Affairs, 1984), 234-35.

82 Yoshida Shigeru, Kaisō 10 Nen [Reflections on a decade], vol. 4 (Tokyo: Shinchōsha, 1958), 102, 148-49.

83 Yoshida to Makino, around the end of February 1930, in 'Makino Nobuaki Kankei Bunsho', Document Department, Reel 77. According to Kase Toshikazu, Yoshida's view was:

Tanaka was somebody who understood politics, but Shidehara was hopeless. The cabinet meeting would end. And even if the ministers were all going to have a meal together, he would simply say 'OK then, goodbye' and return to the Ministry of Foreign Affairs. We had a senior official dining saloon, and we would all pass a little time eating something like curry rice and chatting about inconsequential matters. You can't deal with politics acting like that. I would usually be the one making up for this deficiency [on Shidehara's behalf].

See Kase Toshikazu, 'Yoshida Shigeru wo Kataru’ [On Yoshida Shigeru], Kasumigaseki-kai Kaihō, no. 280 (January 1969): 16-17.

84 It was already a different age from that of the Paris Peace Conference when Williams, the former chief of the US State Department's Division of Far Eastern Affairs, had heaped praise on Wellington Koo, plenipotentiary representative for China. Conversely, Williams was scornful of plenipotentiary Makino, who stubbornly persisted in fighting for Japan's interests in Shandong. See Castle's diary, vol. 16, 5, 6, 11 February, 16, 29 March, 12, 17 April, and 17, 21, 28, 31 May 1930. See also Shidehara to Makino, 7 June 1930, in 'Makino Nobuaki Kankei Bunsho', Document Department, Reel 37; Williams (Paris) to Breckinridge Long (Washington, DC, third assistant secretary of state), 21 February 1919, Williams Papers, Box 1; Higuchi, Nihon Kaigun kara Mita Nicchu Kankei-shi Kenkyū, 121.

85 Castle to Stimson, 10 March 1930, Records of the U.S. Department of State Relating to the Internal Affairs of Japan, 1930-1939, Reel 1.

86 Hori Teikichi journal, 25 March 1930, in Kobayashi and Shimada, Gendai-shi Shiryo, vol. 7, 37.

87 Nagai Ryūtarō, 'Shidehara Gaikō to Tai-Shi Bōeki no Kōten’ [Shidehara diplomacy and the improvement of trade with China], Minsei 3, no. 11 (November 1929): 28-29; Nagai Ryūtarō, 'Shidehara Gaikō no Konpon Hōshin to London Jōyaku' [The fundamental orientation of Shidehara diplomacy and the London treaty], Minsei 4, no. 9 (September 1930): 26-31. For more recent 
research on Nagai Ryūtarō, see Sakamoto Kenzō, 'Nagai Ryūtarō no Nicchū Teikei-ron: Daiichiji Taisen-ki wo Chūshin ni' [Nagai Ryūtarō’s argument for Sino-Japanese Partnership: Focusing on the era of World War I], Hōgaku Kenkyū 73, no. 9 (September 2000): 33-73.

88 Extraordinary meeting of the supreme council of the Navy, 15 March 1930, in Inaba et al., Taiheiyō Sensō eno Michi, extra vol.: Resources, 13; Katō's diary entry for 18 February includes the following: 'Spoke with Shidehara on the topic of "Castle" and the U.S. Navy planning for a potential Tokyo air raid'. See Itō et al., Zoku Gendai-shi Shiryō, vol. 5, 92.

89 This situation improved after the war, as the role of US ambassador to Japan became important. Figures who took this position included former Harvard University Professor Edwin O. Reischauer, future undersecretary of state U. Alexis Johnson, Labor Secretary James D. Hodgson, Democratic Party Senate Floor Leader Michael Mansfield, former vice president Walter F. Mondale and former house speaker Thomas S. Foley. For general information on US ambassadors to Japan in the postwar period, see Ikei Masaru, Chu-Nichi America Taishi [US ambassadors to Japan] (Tokyo: Bungei Shunjū, 2001).

90 As Minohara Toshihiro pointed out, according to what Dooman told Castle, the phrasing 'grave consequences' contained within the Hanihara letter, which was an important moment in passing the Japanese Exclusion Act, was written by MacMurray, the chief of the State Department's Division of Far Eastern Affairs. Dooman learned of this from Taketomi Toshihiko, chief of the International Trade Bureau at the Ministry of Foreign Affairs. Castle trusted Dooman and wrote in his diary, 'Dooman I like immensely. His knowledge of things Japanese is endless'. See Castle's diary, vol. 16, 11, 25 February 1930; Minohara, Hai-Nichi Imin-hō to Nichi-Bei Kankei, 197.

It should be noted that Dooman himself publicly reflected upon the link between the Japanese Exclusion Act and the 'grave consequences' phrasing. In a May 1962 interview, Dooman recalled the address of Sakatani Yoshirō, member of the House of Peers, who stated that, if the Japanese Exclusion Act were passed, 'it would prejudice the willingness of the Japanese people to continue in the collaboration which was the ultimate object of the nine-power treaty'. He then began to speak on the circumstances surrounding the Hanihara letter. According to Dooman, when Secretary of State Hughes requested that Hanihara Masanao, Japan's ambassador to the US, write a letter addressed to Hughes, Hanihara wrote the letter draft while consulting Sakatani's address to the House of Peers.

According to Dooman, although Sakatani saw the passage of the Japanese Exclusion Act as entailing 'grave consequences', what Sakatani meant by those 'grave consequences' was not war or something similar but Japan's abandoning cooperation with the other Great Powers on China policy. Dooman stated that this was the actual context within which Hanihara used the expression 'grave consequences'. Hughes and MacMurray, who confidentially received a copy of the draft from Hanihara, proposed several revisions. They did not, at this stage, object to the language of 'grave consequences', giving it their implicit consent. Yet this expression would then be singled out by individuals such as Senate Diplomatic Affairs Committee Chief Henry Cabot Lodge, who criticised it as representing a threat. As a result, according to Dooman, the Japanese Exclusion Act was passed. See reminiscences of Dooman.

There are no surviving ministry records that provide evidence of a causal relationship between the Sakatani address and Hanihara letter. That said, at the very least, with respect to his remarks on the Sakatani address, Dooman's recollections are basically correct. In his address to the House of Peers on 23 January 1924, Sakatani began by remarking that he had 'a deep affection' for the US. Yet, he expressed concerns about the efforts of individuals such as Albert Johnson and John E. Raker in the US Congress. For Sakatani, if the Japanese Exclusion Act were to pass, it would 'lead to an extremely loathsome result for Japan-U.S. relations'. Sakatani forcefully argued that, even if it did not lead to war, such a decision would be 'completely inconsistent with the spirit of the naval limitation treaty that was agreed upon at the famous Washington Naval Conference, as well as with the spirit of other such treaties'. As Dooman also noted, Sakatani, who had served as honorary vice-president of the America-Japan Society, had no reason to risk a possible war between the two nations.

On Sakatani's address, see Teikoku Gikai Kizokuin Giji Sokkiroku, vol. 44: Dai 48, 49-kai Gikai, Taishō 12 Nen [Shorthand record of the proceedings of the Imperial Diet House of Peers, vol. 44: Diet Nos 48, 49, Taisho 12] (Tokyo: University of Tokyo Press, 1982), 47-49. Also see Viscount Sakatani 
Memorial Project Foundation, ed., Sakatani Yoshirō Den [The biography of Sakatani Yoshirō] (Tokyo: Viscount Sakatani Memorial Project Foundation, 1951), 706. Texts that shed light on Sakatani's perspective on the US include Sakatani Sōkō [Sakatani Manuscript], 6 June 1921, in 'Sakatani Yoshirō Kankei Bunsho', Document Department, no. 812; address given to the directors of the Japan Peace Society by Sakatani, 13 May 1921, in Japan Advertiser, 24 June 1921, in 'Sakatani Yoshirō Kankei Bunsho', Document Department, no. 814.

At that time, Sakatani debated the Japanese Exclusion Act with a number of individuals, including Foreign Minister Matsui Keishirō; Saburi Sadao, who, after returning to Japan, became the acting director of the International Trade Bureau at the Ministry of Foreign Affairs; Akamatsu Sukeyuki, director of the Immigration Division at the International Trade Bureau; Sawada Setsuzō, director of both the correspondence section and the translation section; Hanihara Masanao, Japan's previous ambassador to the US; and Cyrus E. Woods, the US ambassador to Japan. For further details on these discussions, see Sakatani Yoshirō's diary, 16, 24 March, 25 April, 24, 25, 27, 28 May and 2, 5 June 1924, in 'Sakatani Yoshirō Kankei Bunsho', Document Department, no. 698; Sakatani’s notebook, 2, 7, February and 1 November 1924, in 'Sakatani Yoshirō Kankei Bunsho', Document Department, no. 751.

For further details on the manner in which Sakatani, as chairman of the Carnegie Endowment for International Peace Economic Research Association, cooperated with matters such as the Manchurian Inquiry, see 'Sakatani Yoshirō Bunsho' [Sakatani Yoshirō documents], nos 60, 81-84, Institute of Social Science Library, the University of Tokyo.

91 Ballantine was also the first to recognise that the 'Tanaka Jōsōbun' [Tanaka memorial] — which was disseminated just before the London conference and handed over to him by Hornbeck-was a fake. See reminiscences of Joseph W. Ballantine, 1961, Oral History Research Office, Columbia University.

92 On the non-governmental side, it was soon time for the fourth Lincoln Essay Contest, an event held for Japanese students and hosted by the America-Japan Society. The awards ceremony, held in March 1930, was attended by the society chairman, Lord Speaker of the House of Peers Tokugawa Iesato, Castle and Dooman. See: America-Japan Society Special Bulletin, no. 10 (1930): 3-9, in 'Nichi-Bei Kyōkai Shiryō', C3-10.

93 Reminiscences of Sansom.

94 Reminiscences of Dooman.

95 On 24 January 1930, just after his visit to Japan, Castle wrote: 'Congress would never go to war over the open door, nor over Japanese annexation of Manchuria-and Japan has no intention of annexing Manchuria'. See Castle diary, vol. 16, 24 January 1930.

However, only the first half of the above statement was actually correct. It must have been a matter of great sorrow for Castle when, during his time as undersecretary, the relations between Japan and the US deteriorated as a result of the Manchurian Incident. Japan's foreign minister at that time was Shidehara. Thus, many Americans were growing increasingly concerned about Japan's foreign policy, while at the same time were irritated at its inability to take more resolute steps.

96 Nagai, 'Shidehara Danshaku no Omoide'.

97 Kuwabara Tsuru, 'Shidehara Danshaku no Omoide' [Memories of Baron Shidehara], Kasumigaseki-kai Kaihō, no. 234 (August 1965): 2-3.

98 Shidehara, Gaikō 50 Nen, 133.

99 Asahi Shimbun, 15 November (evening edition) and 16 November (evening edition) 1930; Shidehara, Gaikō 50 Nen, 133-44.

100 Itō and Hirose, Makino Nobuaki Nikki, 420-21; Izawa Takio Biography Compilation Committee, Izawa Takio, 197-198; Ōnishi Hiroshi, 'Izawa Takio to Ugaki Kazushige: Ugaki Yōritsu Kōsaku wo Chūshin ni' [Izawa Takio and Ugaki Kazushige: Focusing on the campaign to support Ugaki], in Ugaki Kazushige to Sono Jidai: Taishō, Shōwa-ki no Gunbu, Seitō, Kanryō [Ugaki Kazushige and his era: The military, political parties, and bureaucracy in the Taishō and Shōwa eras], ed. Hori Makiyo (Tokyo: Shinhyōron, 1999), 248.

101 Itō and Hirose, Makino Nobuaki Nikki, 441. 
102 Debuchi to Shidehara, 5 June 1931, in 'Yardley-cho, American Black Chamber Mondai Ikken' [The problem of Yardley's The American Black Chamber], N.2.2.0.9, Diplomatic Archives of the Ministry of Foreign Affairs of Japan; Herbert O. Yardley, The American Black Chamber (New York: Blue Ribbon Books, 1931); Ministry of Foreign Affairs Hundred-Year History Compilation Association, Gaimushō no 100 Nen, vol. 2, 1329-38; John Prados, Combined Fleet Decoded: The Secret History of American Intelligence and the Japanese Navy in World War II (Annapolis: Naval Institute Press, 1995), 12-13, 69.

103 Ministry of Foreign Affairs, Nihon Gaikō Bunsho, Shōwa Era I, part 1, vol. 4, 1041-1045; Kawashima Shin, "Shina” "Shina-koku” "Shina Kyōwakoku”: Nihon Gaimushō no Tai-Chu Koshō Seisaku' ['Shina', 'Nation of Shina', 'The Republic of Shina': The Japanese Ministry of Foreign Affairs' China-naming policy], Chügoku Kenkyū Geppō 49, no. 9 (September 1995): 1-15; Yu Hong, 'Dainiji Shidehara Gaikō-ki niokeru Chugoku no Kokugō Koshō Mondai: "Shina Kyōwakoku” kara "Chūka Minkoku" e' [The problem of the naming of China during the second period of Shidehara diplomacy: From the 'Chinese Republic' to the 'Republic of China'], Ochanomizu Shigaku, no. 46 (2002): 79-108.

104 Shidehara Kijūrō, 'Kokusai Heiwa to Sekai no Taisei' [International peace and the global situation], (originally a radio lecture given on 11 November 1929), Gaikö Jihō, no. 601 (December 1929): 162 .

105 Hattori, Higashi Asia Kokusai Kankyō no Hendō to Nihon Gaikō, 1918-1931, 263-78.

106 Kobayashi and Shimada, Gendai-shi Shiryo, vol. 7, 184; Kobayashi Tatsuo, Shimada Toshihiko and Inaba Masao, eds, Gendai-shi Shiryo, vol. 11: Zoku Manshü Jihen [Modern historical material, vol. 11: Continued, the Manchurian Incident] (Tokyo: Misuzu Shobō, 1965), 313.

See also Morishima Morito, Inbō, Ansatsu, Guntō [Conspiracy, assassination, military swords] (Tokyo: Iwanami Shoten, 1950), 49; Seki Hiroharu, 'Manshū Jihen Zenshi' [The prehistory of the Manchurian Incident], in Japanese International Politics Society Research Division for Causes of the Pacific War, Taiheiyō Sensō eno Michi, vol. 1, 412, 419, 433; Shimada Toshihiko, 'Manshū Jihen no Tenkai' [The unfolding of the Manchurian Incident], in Taiheiyō Sensō eno Michi, ed. Japanese International Politics Society Research Division for Causes of the Pacific War, vol. 2 (Tokyo: Asahi Shimbun, 1962), 12-13; Ogata Sadako, Manshü Jihen to Seisaku no Keisei Katei [The Manchurian Incident and the policy formation process] (Tokyo: Hara Shobō, 1966), 104; Hayashi Kyūjirō, Manshū Jihen to Hōten Söryōji: Hayashi Kyüjirō Ikō [The Manchurian Incident and the Japanese consul general in Mukden: The posthumous manuscript of Hayashi Kyūjirō] (Tokyo: Harashobō, 1978), 114-15.

107 Inaba et al., Taiheiyō Sensō eno Michi, extra vol.: Resources, 114-15.

108 Ibid., 123.

109 I have previously written on the above circumstances and on response to the Lytton Commission. See Hattori, Higashi Asia Kokusai Kankyō no Hendō to Nihon Gaikō, 1918-1931, 278-88; Hattori, Manshü Jihen to Shigemitsu Chüka Köshi Hökokusho.

110 Stimson diary, 27 November 1931, Stimson Papers, Reel 4.

111 Forbes to Stimson, 24 November 1931, in FRUS, Japan: 1931-1941, ed. Department of State, vol. 1 (Washington: Government Printing Office, 1945), 50.

112 Tokyo Asahi Shimbun, evening edition, 29 November 1931.

113 Stimson diary, 22, 24, 26, 27, 28 November 1931, Stimson Papers, Reel 4; Shidehara to Debuchi, 28 November 1931, in Nihon Gaikō Bunsho: Manshü Jihen [Documents on Japanese foreign policy: The Manchurian Incident], Ministry of Foreign Affairs, vol. 1, no. 3 (Tokyo: Ministry of Foreign Affairs, 1978), 113-14; Takahashi Katsuhiro, ed., “'Debuchi Katsuji Nikki” (3): Shōwa 6 Nen-8 Nen' [The diary of Debuchi Katsuji (3): Shōwa 6-8], Kokugakuin Daigaku Nihon Bunka Kenkyü-jo Kiyo, no. 86 (September 2000): 120-21.

114 Tokyo Asahi Shimbun, extra edition, 29 November 1931. 
115 Shidehara to Debuchi, 29 November 1931, in Ministry of Foreign Affairs, Nihon Gaikö Bunsho: Manshü Jihen, vol. 1, no. 3, 117-19; Harada, Saionji-kö to Seikyoku, vol. 2 (Tokyo: Iwanami Shoten, 1951), 147; Tokyo Asahi Shimbun, 30 November 1931.

116 Banno Junji, Kindai Nihon no Gaikō to Seiji [Modern Japanese diplomacy and politics] (Tokyo: Kenbun Shuppan, 1985), 185-211.

117 Journal of W. Cameron Forbes, William Cameron Forbes Papers, second series, vol. 2, Houghton Library, Harvard University. For further details on Forbes, see Gary Ross, 'W. Cameron Forbes: The Diplomacy of a Darwinist', in Diplomats in Crisis: United States-Chinese-Japanese Relations, 1919-1941, ed. Richard Dean Burns and Edward M. Bennett (Santa Barbara: ABC-Clio, 1974), 49-64.

118 Journal of Forbes, 27, 29 September, 8, 15, 18 October, 3, 14 November and 30 December 1930, and 12 April, 7 May, 2, 21, August and 14 September 1931, Forbes Papers, second series, vol. 3.

119 Shidehara to Ōta Masahiro, governor-general of Taiwan, 24 June 1931, in 'Shidehara Heiwa Bunko', Reel 17. I received advice on this topic from Asano Toyomi.

120 Journal of Forbes, 24 September and 17 November 1931, Forbes Papers, second series, vol. 3.

121 Journal of Forbes, 3 December 1931, Forbes Papers, second series, vol. 3. See also Forbes to Stimson, 28 November 1931, in Stanley K. Hornbeck Papers, Box 167, Hoover Institution, Stanford University. For further details on Shiratori in this period, see Tobe Ryōichi, 'Shiratori Toshio to Manshū Jihen' [Shiratori Toshio and the Manchurian Incident], Böei Daigakkō Kiyō, no. 39 (September 1979): 77-130.

122 Journal of Forbes, 3 December 1931.

123 Harada, Saionji-kō to Seikyoku, vol. 2, 149-50.

124 Forbes to Stimson, 2 December 1931, in Journal of Forbes, Forbes Papers, second series, vol. 4; Forbes to Joseph C. Grew, 14 March 1932, in Journal of Forbes, Forbes Papers, second series, vol. 4.

125 Shidehara to Forbes, 24 November 1932, in Journal of Forbes, Forbes Papers, second series, vol. 4; Forbes to Shidehara, 22 December 1932, in Journal of Forbes, Forbes Papers, second series, vol. 4. Shidehara's correspondence was also passed from Forbes to Hornbeck. See Forbes to Hornbeck, 22 December 1932, Hornbeck Papers, Box 167.

126 Forbes to Stimson, 29 November 1931, in FRUS, 1931, ed. Department of State, vol. 3 (Washington: Government Printing Office, 1945), 587-88; Stimson to Forbes, 30 November, ibid., 595-96. 
This text is taken from Japan at War and Peace: Shidehara Kijürō and the Making of Modern Diplomacy, by Ryuji Hattori, published 2021 by ANU Press, The Australian National University, Canberra, Australia.

doi.org/10.22459/JWP.2021.05 